Article

\title{
Synthetic Routes to N-9 Alkylated 8-Oxoguanines; Weak Inhibitors of the Human DNA Glycosylase OGG1
}

\author{
Tushar R. Mahajan ${ }^{1}$, Mari Eknes Ytre-Arne ${ }^{2,3}$, Pernille Strøm-Andersen ${ }^{3}$, Bjørn Dalhus ${ }^{2,3}$ \\ and Lise-Lotte Gundersen 1,*
}

1 Department of Chemistry, University of Oslo, P. O. Box 1033, Blindern, N-0315 Oslo, Norway; E-Mail: t.r.mahajan@kjemi.uio.no

2 Department of Microbiology, Oslo University Hospital, P. O. Box 4950, Nydalen, N-0424 Oslo, Norway; E-Mails: Mari.Ytre-Arne@rr-research.no (M.E.Y.-A.); Bjorn.Dalhus@medisin.uio.no (B.D.)

3 Department of Medical Biochemistry, Institute of Clinical Medicine, University of Oslo, P. O. Box 4950, Nydalen, N-0424 Oslo, Norway; E-Mail: pernille.strom-andersen@medisin.uio.no

* Author to whom correspondence should be addressed; E-Mail: 1.1.gundersen@kjemi.uio.no; Tel.: +47-228-570-19.

Academic Editor: Roman Dembinski

Received: 2 June 2015 / Accepted: 26 August 2015 / Published: 2 September 2015

\begin{abstract}
The human 8-oxoguanine DNA glycosylase OGG1 is involved in base excision repair (BER), one of several DNA repair mechanisms that may counteract the effects of chemo- and radiation therapy for the treatment of cancer. We envisage that potent inhibitors of OGG1 may be found among the 9-alkyl-8-oxoguanines. Thus we explored synthetic routes to 8-oxoguanines and examined these as OGG1 inhibitors. The best reaction sequence started from 6-chloroguanine and involved $N-9$ alkylation, $C-8$ bromination, and finally simultaneous hydrolysis of both halides. Bromination before $N$-alkylation should only be considered when the $N$-substituent is not compatible with bromination conditions. The 8-oxoguanines were found to be weak inhibitors of OGG1. 6-Chloro-8-oxopurines, byproducts in the hydrolysis of 2,6-halopurines, turned out to be slightly better inhibitors than the corresponding 8-oxoguanines.
\end{abstract}

Keywords: alkylation; cancer; DNA; enzyme inhibitors; guanine; halogenation 


\section{Introduction}

Chemo- and radiotherapy are, in addition to surgery for removal of solid tumors, the two main treatment protocols currently available to improve the outcome of cancer patients in general, but treatment-related toxicity, the risk of secondary cancers, and the emergence of resistance limit their effectiveness [1]. Some chemotherapeutic drugs and radiotherapy work partly by imposing high concentrations of DNA damage on the genome of cancer cells, beyond the repair capacity of those cells. The drug-exposed cancer cells are heavily dependent on efficient DNA repair to survive. Consequently, inhibitors that reduce DNA repair activities should sensitize cancer cells to chemo- and/or radiotherapy [2-5].

Several DNA repair mechanisms counteract exogenous and endogenous processes that destabilize or directly damage genomes. The processes include, among others, base excision repair (BER), a mechanism that depends on enzymes that recognize small modifications in the native bases in DNA, resulting from alkylation, oxidation, deamination, or hydrolysis of the DNA bases. The pathway is initiated by a damage-specific DNA glycosylase that removes the altered base [6]. Some of these enzymes mainly remove oxidized bases, such as the human 8-oxoguanine DNA glycosylase (OGG1) that removes guanines that have been oxidized at the C8-position. The 8-oxoguanine base in the DNA is flipped into a lesion recognition pocket on the enzyme surface, exposing the Watson-Crick signature of guanine and the oxidized C8 position (Figure 1).

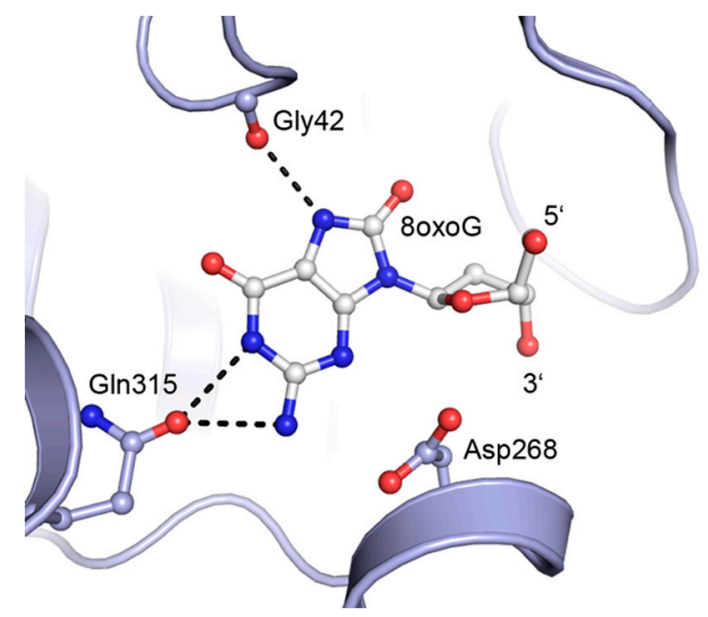

Figure 1. Structural details of 8oxoG base flipped into the lesion recognition pocket of OGG1 (Protein Data Bank deposition 1EBM [7]). The protein backbone is shown as a blue ribbon/helix. Selected amino acid side chains and the 8 oxoG base are shown as ball-and-stick. Hydrogen bonds between the protein and $80 x 0 \mathrm{G}$ are shown as dashed lines. Asp268 is the catalytic residue in OGG1. Symbols $5^{\prime}$ and $3^{\prime}$ indicate the position of the $5^{\prime}$ and $3^{\prime}$ phosphodiester links in the DNA.

We envisage that potent inhibitors of OGG1 may be found among the 9-alkyl-8-oxoguanines. The 8-oxo derivatives of guanosine or deoxyguanosine are probably not inhibitors of the glycosylases since they themselves may be substrates for the enzymes that cleave $\mathrm{N}, \mathrm{O}$-acetals in nucleic acids. As a continuance of our synthetic studies directed towards 9-substituted 8-oxoadenines [8,9], we herein present strategies for the synthesis of $\mathrm{N}-9$ substituted 8-oxoguanines. Previous routes include rather tedious constructions of the guanine ring system [10-12], and hydrolysis of purine precursors; hydrolysis of 
8-halopurines [13-16], or less conveniently hydrolysis of $N$-7 functionalizedpurines [11,17-19]. Results regarding inhibitory activity against the human DNA glycosylase OGG1 are also presented.

\section{Results and Discussion}

\subsection{Chemistry}

We found it most convenient to start the synthesis of 9-alkyl-8-oxopurines from commercially available purines, and in our opinion the best way to introduce the 8-oxo group would be by hydrolysis of an 8 -halopurine. However, there still was the question of whether the halogen or the $N-9$ substituent should be introduced first and which protection/activation groups should be employed in the synthesis. Ideally, such groups should also be removed in the final hydrolysis step. Regioselectivity in $N$-alkylation of guanine derivatives was also an issue [20-27]. We chose to start from two guanine precursors, commercially available 2-amino-6-chloropurine (1a) and the $O$-carbamoylguanine $\mathbf{1 b}$, easily available from guanine [28,29]. The synthetic routes explored are all summarized in Scheme 1.



Reagents and conditions: (a) See Table 1; (b) See Table 2; (c) 1. $\mathrm{Ac}_{2} \mathrm{O}, \mathrm{NaOAc}, \mathrm{AcOH}, 2$. $\mathrm{NaOH}(\mathrm{aq}), \Delta$; (d) 1. LDA, 2. $\left(\mathrm{CCl}_{2} \mathrm{Br}\right)_{2}, \mathrm{THF},-78{ }^{\circ} \mathrm{C}$; (e) $\mathrm{Br}_{2}, \mathrm{CHCl}_{3}$; (f) See [30]; (g) $\mathrm{HCl}(\mathrm{aq}), \mathrm{EtOH}$.

Scheme 1. Synthetic routes to 8-oxoguanines 5. 
Table 1. $N$-alkylation of guanine precursors $\mathbf{1 a}$ and $\mathbf{1 b}$.

\begin{tabular}{|c|c|c|c|c|c|c|c|}
\hline Entry & $\mathbf{R}^{2}$ & $\mathbf{R}^{6}$ & $\mathbf{R}$ & $\begin{array}{c}\text { Reagents and } \\
\text { Conditions } \\
\end{array}$ & Ratio 2:3:1 ${ }^{\text {a }}$ & Yield (\%) $2^{b}$ & Yield (\%) $3^{b}$ \\
\hline 1 & $\mathrm{Cl}$ & $\mathrm{NH}_{2}$ & $\mathrm{CH}_{2}-c$-hexyl & $\begin{array}{l}\mathrm{RBr}, \mathrm{K}_{2} \mathrm{CO}_{3}, \\
\mathrm{DMF}, \mathrm{rt}, 72 \mathrm{~h}\end{array}$ & $80: 20: 0$ & $67, \mathbf{2 a}$ & $10, \mathbf{3 a}$ \\
\hline 2 & $\mathrm{Cl}$ & $\mathrm{NH}_{2}$ & $\mathrm{CH}_{2}-c$-hexyl & $\begin{array}{l}\text { ROH, DIAD, } \mathrm{PPh}_{3}, \\
\mathrm{THF}, 70^{\circ} \mathrm{C}, 14 \mathrm{~h}\end{array}$ & $93: 7: 0$ & $76, \mathbf{2 a}$ & $5, \mathbf{3 a}$ \\
\hline 3 & $\mathrm{OCONPh}_{2}$ & NHAc & $\mathrm{CH}_{2}-c$-hexyl & $\begin{array}{l}\mathrm{RBr}, \mathrm{K}_{2} \mathrm{CO}_{3}, \\
\mathrm{DMF}, \mathrm{rt}, 72 \mathrm{~h}\end{array}$ & 81:19:0 & $45, \mathbf{2 e}$ & $7, \mathbf{3 e}$ \\
\hline 4 & $\mathrm{OCONPh}_{2}$ & NHAc & $\mathrm{CH}_{2}-c$-hexyl & $\begin{array}{l}\text { ROH, DIAD, } \mathrm{PPh}_{3}, \\
\mathrm{THF}, 70^{\circ} \mathrm{C}, 14 \mathrm{~h}\end{array}$ & $82: 18: 0$ & $70, \mathbf{2 e}$ & $3,3 e$ \\
\hline 5 & $\mathrm{Cl}$ & $\mathrm{NH}_{2}$ & $c$-hexyl & $\begin{array}{l}\mathrm{RI}, \mathrm{K}_{2} \mathrm{CO}_{3}, \\
\mathrm{DMF}, \mathrm{rt}, 72 \mathrm{~h}\end{array}$ & $15: 0: 85$ & $-{ }^{c}$ & - \\
\hline 6 & $\mathrm{Cl}$ & $\mathrm{NH}_{2}$ & $c$-hexyl & $\begin{array}{l}\text { ROTs, } \mathrm{K}_{2} \mathrm{CO}_{3}, \\
\text { DMF, rt, } 72 \mathrm{~h}\end{array}$ & $-{ }^{\mathrm{d}}$ & $33, \mathbf{2 b}$ & $-{ }^{c}$ \\
\hline 7 & $\mathrm{Cl}$ & $\mathrm{NH}_{2}$ & $c$-hexyl & $\begin{array}{l}\text { ROH, DIAD, } \mathrm{PPh}_{3}, \\
\mathrm{THF}, 70^{\circ} \mathrm{C}, 14 \mathrm{~h}\end{array}$ & $8: 4: 88$ & $-{ }^{\mathrm{c}}$ & $-{ }^{c}$ \\
\hline 8 & $\mathrm{Cl}$ & $\mathrm{NH}_{2}$ & $c$-hexyl & $\begin{array}{l}\text { ROH, DIAD, } \mathrm{PPh}_{3} \text {, } \\
\text { THF, ultrasound, } 14 \mathrm{~h}\end{array}$ & $27: 0: 73$ & $20, \mathbf{2 b}$ & - \\
\hline 9 & $\mathrm{Cl}$ & $\mathrm{NH}_{2}$ & $c$-hexyl & $\begin{array}{l}\text { ROH, DIAD, } \mathrm{PPh}_{3}, \\
\text { DMF, } 150^{\circ} \mathrm{C}, \mu \mathrm{W}, 2 \mathrm{~h}\end{array}$ & $41: 8: 51$ & $-{ }^{\mathrm{c}}$ & $-{ }^{\mathrm{c}}$ \\
\hline 10 & $\mathrm{OCONPh}_{2}$ & NHAc & $c$-hexyl & $\begin{array}{l}\text { ROTs, } \mathrm{K}_{2} \mathrm{CO}_{3}, \\
\text { THF, rt, } 72 \mathrm{~h}\end{array}$ & $-{ }^{d}$ & $30, \mathbf{2 f}$ & $-{ }^{c}$ \\
\hline 11 & $\mathrm{OCONPh}_{2}$ & NHAc & $c$-hexyl & $\begin{array}{l}\text { ROTs, } \mathrm{K}_{2} \mathrm{CO}_{3}, \mathrm{DMF}, \\
80^{\circ} \mathrm{C}, 72 \mathrm{~h}\end{array}$ & $-{ }^{\mathrm{d}, \mathrm{e}}$ & $-{ }^{\mathrm{c}}$ & $-{ }^{c}$ \\
\hline 12 & $\mathrm{OCONPh}_{2}$ & NHAc & $c$-hexyl & $\begin{array}{l}\text { ROH, DIAD, } \mathrm{PPh}_{3} \text {, } \\
\mathrm{THF}, 70^{\circ} \mathrm{C}, 14 \mathrm{~h}\end{array}$ & $-{ }^{d}$ & $22, \mathbf{2 f}$ & $-{ }^{c}$ \\
\hline 13 & $\mathrm{Cl}$ & $\mathrm{NH}_{2}$ & $c$-pentyl & $\begin{array}{l}\mathrm{RBr}, \mathrm{K}_{2} \mathrm{CO}_{3}, \\
\mathrm{DMF}, \mathrm{rt}, 72 \mathrm{~h}\end{array}$ & $86: 14: 0$ & $71, \mathbf{2 c}$ & $5,3 \mathrm{c}$ \\
\hline 14 & $\mathrm{Cl}$ & $\mathrm{NH}_{2}$ & $c$-pentyl & $\begin{array}{l}\mathrm{ROH}, \mathrm{DIAD}, \mathrm{PPh}_{3}, \\
\mathrm{THF}, 70^{\circ} \mathrm{C}, 14 \mathrm{~h}\end{array}$ & $91: 9: 0$ & $72, \mathbf{2 c}$ & $6,3 \mathrm{c}$ \\
\hline 15 & $\mathrm{OCONPh}_{2}$ & NHAc & $c$-pentyl & $\begin{array}{l}\mathrm{RBr}, \mathrm{K}_{2} \mathrm{CO}_{3}, \\
\mathrm{DMF}, \mathrm{rt}, 72 \mathrm{~h}\end{array}$ & 76:15:09 & $52, \mathbf{2 g}$ & $-{ }^{c}$ \\
\hline 16 & $\mathrm{OCONPh}_{2}$ & NHAc & $c$-pentyl & $\begin{array}{l}\mathrm{ROH}, \mathrm{DIAD}, \mathrm{PPh}_{3}, \\
\mathrm{THF}, 70^{\circ} \mathrm{C}, 14 \mathrm{~h}\end{array}$ & $90: 10: 0$ & $58,2 \mathrm{~g}$ & $-{ }^{c}$ \\
\hline 17 & $\mathrm{Cl}$ & $\mathrm{NH}_{2}$ & $c$-pent-2-enyl & $\begin{array}{l}\mathrm{RBr}, \mathrm{K}_{2} \mathrm{CO}_{3}, \\
\mathrm{DMF}, \mathrm{rt}, 24 \mathrm{~h}\end{array}$ & $23: 16: 61$ & $18, \mathbf{2 d}$ & $-{ }^{\mathrm{c}}$ \\
\hline 18 & $\mathrm{Cl}$ & $\mathrm{NH}_{2}$ & $c$-pent-2-enyl & $\begin{array}{l}\text { ROH, DIAD, } \mathrm{PPh}_{3}, \\
\mathrm{THF}, 70^{\circ} \mathrm{C}, 42 \mathrm{~h}\end{array}$ & $55: 18: 27$ & $40, \mathbf{2 d}$ & $-{ }^{c}$ \\
\hline 19 & $\mathrm{Cl}$ & $\mathrm{NH}_{2}$ & $c$-pent-2-enyl & $\begin{array}{l}\mathrm{ROAc}, \mathrm{Pd}\left(\mathrm{PPh}_{3}\right)_{4}, \mathrm{NaH}, \\
\mathrm{DMSO},{ }^{\mathrm{f}} 50^{\circ} \mathrm{C}, 48 \mathrm{~h}\end{array}$ & $75: 25: 0$ & $53, \mathbf{2 d}$ & $18, \mathbf{3 d}$ \\
\hline
\end{tabular}

${ }^{a}$ From ${ }^{1} \mathrm{H}-\mathrm{NMR}$ spectra of the crude products, the signals from $\mathrm{H}-8$ in compounds $\mathbf{1}, \mathbf{2}$, and $\mathbf{3}$ were integrated;

${ }^{\mathrm{b}}$ Isolated yields; ${ }^{\mathrm{C}}$ Not isolated in pure form; ${ }^{\mathrm{d}}$ Difficult to determine due to overlapping signals in the ${ }^{1} \mathrm{H}-\mathrm{NMR}$ spectra; ${ }^{\mathrm{e}} \mathrm{A}$ complex mixture was formed; ${ }^{\mathrm{f}}$ Comparable results were obtained in DMF. 
Table 2. Synthesis of 8-bromopurines 4.

\begin{tabular}{cclc}
\hline Entry & Starting Material $^{\mathbf{a}}$ & \multicolumn{1}{c}{ Reagents and Conditions } & Yield (\%) 4 $\mathbf{4}$, \\
\hline 1 & $\mathbf{2 a}$ & $\mathrm{Br}_{2}, \mathrm{H}_{2} \mathrm{O}$ & $79 \%, \mathbf{4 a}$ \\
2 & $\mathbf{1 0}$ & $\mathrm{RBr}, \mathrm{K}_{2} \mathrm{CO}_{3}, \mathrm{DMF}$ & $34 \%, \mathbf{4 a}$ \\
3 & $\mathbf{1 0}$ & $\mathrm{ROH}, \mathrm{DIAD}, \mathrm{PPh}_{3}, \mathrm{THF}, 70{ }^{\circ} \mathrm{C}$ & $56 \%, \mathbf{4 a}$ \\
4 & $\mathbf{2 b}$ & $\mathrm{Br}_{2}, \mathrm{H}_{2} \mathrm{O}$ & $70 \%, \mathbf{4 b}$ \\
5 & $\mathbf{2 c}$ & $\mathrm{Br}_{2}, \mathrm{H}_{2} \mathrm{O}$ & $81 \%, \mathbf{c}$ \\
6 & $\mathbf{2 d}$ & $1 . \mathrm{LDA}, 2 . \mathrm{CCl}_{2} \mathrm{BrCCl}_{2} \mathrm{Br}, \mathrm{THF},-78{ }^{\circ} \mathrm{C}$ & $32 \%, \mathbf{4 d}$ \\
7 & $\mathbf{1 0}$ & $\mathrm{ROH}, \mathrm{DEAD}, \mathrm{PPh}_{3}, \mathrm{THF}, 70{ }^{\circ} \mathrm{C}$ & $42 \%, \mathbf{4 d}$ \\
8 & $\mathbf{1 0}$ & $\mathrm{ROAc}, \mathrm{Pd}\left(\mathrm{PPh}_{3}\right)_{4}, \mathrm{NaH}, \mathrm{DMF}, 50{ }^{\circ} \mathrm{C}$ & $29 \%, \mathbf{4 d}$ \\
\hline
\end{tabular}

a The structures are shown in Scheme $1 ;{ }^{b}$ Isolated yields.

First we chose to $N$-alkylate the substrates 1 before $C-8$ halogenation and hydrolysis. Alkylations were conducted by various methodologies in order to find the conditions that gave the desired $N-9$ alkylated isomer 2 with high selectivity and in a good isolated yield (Scheme 1, Table 1). Relatively simple alkylating agents were chosen for the model reactions and we focused on alkylation with alkyl halides in the presence of base, Mitsunobu reactions, and Pd-catalyzed allylic alkylation.

The cyclohexylmethyl substituent could be introduced at $N-9$ either by reaction with alkyl bromide in the presence of a base [31,32] (Table 1, Entries 1 and 3) or with cyclohexylmethanol under Mitsunobu conditions (Table 1, Entries 2 and 4). The latter is often claimed to be more $N$-9 selective compared to classical alkylations of purines [33-35]. In all cases a mixture of the $N-9$ and $N-7$ alkylated isomers ( 2 and $\mathbf{3}$ ) was formed with good selectivity for the desired isomer $\mathbf{2}$. The isomers were identified from HMQC and HMBC-NMR, as described before [31].

The guanine precursor $\mathbf{1 b}$, carrying a bulky substituent at $C-6$ that may sterically block $N-7$, is reported to react with high $N-9$ selectivity in other $N$-functionalization reactions [28,29,36-41]. Nevertheless, we found the regioselectivity in $N$-alkylation of purine $\mathbf{1 b}$ equal or slightly poorer compared to 6-chloroguanine $\mathbf{1 a}$ in all reactions performed in this study. In the alkylation of compound $\mathbf{1 b}$, minor amounts of other relatively polar products were formed under both reaction conditions. These often made purification of the $N-7$ alkylated isomer 3 difficult. The identity of the byproducts could not be determined, but they may be formed as a result of cleavage of the $\mathrm{O}^{6}$-protecting group. Alkylation of $\mathrm{N}^{2}$, as observed by others [41], was not seen.

Introduction of the cyclohexyl group at N-9 turned out to be quite difficult (Table 1, Entries 5-12). Both starting materials (1a and 1b) did not react with cyclohexyl bromide (data not shown) and reacted slowly with cyclohexyl iodide or the corresponding tosylate, but compounds $\mathbf{2 b}$ and $\mathbf{2} \mathbf{f}$ could be isolated in modest yields (Table 1, Entries 5, 6, 10 and 11). It is, however, well known that cyclohexyl halides or pseudo halides may react sluggishly in substitution reactions [42]. The results were not significantly improved when the Mitsunobu reaction was employed (Table 1; Entries 7, 8, and 12), not even under ultrasound (Table 1, Entry 8) or microwave conditions (Table 1, Entry 9).

The cyclopentyl group could easily be installed at $N-9$ on both starting materials $1 \mathbf{a}$ and $\mathbf{1 b}$ by reaction with cyclopentyl bromide and base (Table 1, Entries 13 and 15) or by alkylation under Mitsunobu conditions (Table 1, Entries 14 and 16). The selectivity for $N-9$ was higher in the Mitsunobu reactions, but the isolated yields were comparable due to more tedious purification when Mitsunobu conditions, also producing phosphine oxides and reduced azodicarboxylates, were employed. 
Finally we introduced the cyclopent-2-enyl group at N-9 (Table 1, Entries 17-19). These reactions were only conducted at the guanine precursor 1a, since we so far had not observed any significant improvement in regioselectivity when compound $\mathbf{1 b}$ was employed and we had observed problems with compounds derived from purine $\mathbf{1 b}$ later in the planned synthetic sequence. In addition to alkylation with the halide and Mitsunobu reaction with the alcohol, we also attempted palladium catalyzed alkylation with the allylic acetate [43]. 3-Bromocyclopentene could only be generated as a $15 \%$ solution in $\mathrm{CCl}_{4}$ and the reagent had a limited stability, probably partly due to traces of the radical initiator used in the synthesis left in the solution [44], which may explain the low yield of product 2d (Table 1, Entry 17). The Mitsunobu reaction between purine 1a and cyclopenten-2-ol was surprisingly slow, and full conversion was not achieved even after several days. Furthermore, the $N-9 / N-7$ selectivity was only ca. 4:1 (Table 1, Entry 18). Pd-catalyzed allylic alkylation of purine $\mathbf{1 a}$ went to completion and gave the isomers $\mathbf{2 d}$ and $\mathbf{3 d}$ in a 4:1 ratio (Table 1, Entry 19).

The 6-chloropurines $\mathbf{2 a}, \mathbf{2} \mathbf{b}$, and $\mathbf{2 c}$ were readily brominated on $C-8$ simply by treatment of bromine in water (Scheme 1; Table 2; Entries 1, 4, and 5). For compound 2d, which has an alkene function, the bromide was introduced by $C-8$ lithiation followed by trapping with $\mathrm{CCl}_{2} \mathrm{BrCCl}_{2} \mathrm{Br}$ (Table 2, Entry 6) $[9,32,45,46]$. However, the yield was surprisingly low and also another route to bromide $\mathbf{4 d}$ was examined (see below). Finally hydrolysis of the dihalopurines 4, employing conditions used for hydrolysis of other 8-bromopurines [13-16,47], gave the 8-oxoguanines 5. Complete conversion was achieved in the hydrolysis compound $\mathbf{4 a}$, whereas small amounts of the partly hydrolyzed chlorides $\mathbf{6}$ where present after hydrolysis of purines $\mathbf{4 b} \mathbf{b} \mathbf{d}$ even after prolonged reaction times.

Attempts to brominate the $O$-carbamoylguanine 2e failed (Scheme 1). Treatment with bromine or lithiation followed by trapping with $\mathrm{CCl}_{2} \mathrm{BrCCl}_{2} \mathrm{Br}$ only resulted in cleavage of the carbamoyl protecting group to give the guanine derivative 7 . When compound $\mathbf{2 e}$ was treated with NBS, no reaction took place at all. Thus, no attempts were made to brominate the carbamoyl protected guanines $\mathbf{2} \mathbf{f}$ and $\mathbf{2 g}$.

Since bromination of the cyclopentenylpurine $\mathbf{2 d}$ turned out to be a challenge, we also examined the possibility for introducing the 8-halo substituent before the $N-9$ alkyl group (Scheme 1). We chose to brominate the THP protected compound 8 [30] and removed the protection group under mild acidic condition, but direct bromination of purine 1a in a moderate yield has also been reported [48].

Alkylation of 8-bromo-6-chloropurin-2-amine (10) by bromomethylcyclohexane in the presence of $\mathrm{K}_{2} \mathrm{CO}_{3} / \mathrm{DMF}$ (Table 2, Entry 2) occurred slowly compared to alkylation of 2-amino-6-chloropurine (1a) under the same set of reaction conditions (for alkylation of compound 1a see Table 1). NMR analysis showed that approximately 50\% of the starting material was intact even after $96 \mathrm{~h}$ reaction time and the desired product was isolated in a low yield. Also, $c a .4 \%$ of $N-7$ alkylated isomer was formed, as judged by NMR. When compound 10 was reacted under Mitsunobu (Table 2, Entry 3) conditions, high conversion ( ca. 95\%) and almost full selectivity towards the desired $N-9$ alkylated isomer 4 a was achieved, as judged by ${ }^{1} \mathrm{H}-\mathrm{NMR}$. However, the product $4 \mathrm{a}$ was isolated only in $56 \%$ due to tedious separation from reduced DIAD. Since compound 10 reacted slower (conventional alkylation) or comparably (Mitsunobu alkylation) to compound 1a, it was concluded that there were no benefits associated with introducing the bromide before the $N$-alkyl group for the synthesis of 8-bromopurines $\mathbf{4 a - c}$.

Also, synthesis of the 9-cyclopentenylpurine 4d by $N$-alkylation of compound $\mathbf{1 0}$ was examined (Table 2, Entries 7 and 8) since bromination of 2-amino-6-chloro-9-cyclopentenylpurine 2d turned out to give only a low yield of the desired product. Again, isolation of the desired product from alkylation 
under Mitsunobu conditions turned out to be troublesome. We tried this Mitsunobu alkylation using the water-soluble azodicarboxylate DMEAD (di-2-methoxyethyl azodicarboxylate) as well as DIAD [49]. Purification of the product was less complicated, but the conversion was low and $c a .40 \%$ of starting material 10 was recovered. Also, Pd-catalyzed allylation turned out to be a very slow reaction and even after six days only $29 \%$ of the desired compound $\mathbf{4 d}$ could be isolated, together with $32 \%$ unconverted starting material $\mathbf{1 0 .}$

\subsection{Biology}

As previously mentioned, our hypothesis was that $\mathrm{N}$-alkyl-8-oxoguanines may inhibit the human 8-oxoguanine DNA glycosylase (OGG1). Other substituents in the purine 8-position are probably not tolerated, for instance 8-bromo- and 8-aminoguanines are reported to be enhancers for OGG1 activity [50]. Thus, the 8-oxoguanines 5 as well as the partly hydrolyzed 6-chloro-8-oxopurines 6 were tested against human DNA glycosylases OGG1 and NTH1. A general structure of the tested compounds is shown in Figure 2 and the results are presented in Tables 3 and 4, and Supplementary Figure S19.<smiles>[X]c1nc(N)nc2[nH]c(=O)[nH]c12</smiles>

Figure 2. General structure of the compounds shown in Table 3.

Table 3. \% Activity of OGG1 in the presence of compounds 5 or $\mathbf{6}$ at $0.2 \mathrm{mM}$ concentration.

\begin{tabular}{cccc}
\hline Compound & $\mathbf{X}$ & $\mathbf{R}$ & \% Activity \\
\hline $\mathbf{5 a}$ & $\mathrm{OH}^{\mathrm{a}}$ & $\mathrm{CH}_{2}-c$-hexyl & $89 \pm 5$ \\
$\mathbf{5 b}$ & $\mathrm{OH}^{\mathrm{a}}$ & $c$-hexyl & $92 \pm 2$ \\
$\mathbf{6 b}$ & $\mathrm{Cl}$ & $c$-hexyl & $70 \pm 11$ \\
$\mathbf{5 c}$ & $\mathrm{OH}$ & $c$-pentyl & $101 \pm 12$ \\
$\mathbf{6 c}$ & $\mathrm{Cl}$ & $c$-pentyl & $72 \pm 9$ \\
$\mathbf{5 d}$ & $\mathrm{OH}$ & $c$-pent-2-enyl & $92 \pm 7$ \\
$\mathbf{6 d}$ & $\mathrm{Cl}$ & $c$-pent-2-enyl & $84 \pm 3$ \\
\hline
\end{tabular}

a The predominant 6-oxo tautomer of compounds 5 is shown in Scheme 1.

Table 4. \% Activity of NTH1 in the presence of compounds 5 or 6 at $0.5 \mathrm{mM}$ concentration.

\begin{tabular}{cccc}
\hline Compound & $\mathbf{X}$ & $\mathbf{R}$ & \% Activity \\
\hline $\mathbf{5 a}$ & $\mathrm{OH}^{\mathrm{a}}$ & $\mathrm{CH}_{2}-c$-hexyl & $96 \pm 3$ \\
$\mathbf{5 b}$ & $\mathrm{OH}^{\mathrm{a}}$ & $c$-hexyl & $123 \pm 20$ \\
$\mathbf{6 b}$ & $\mathrm{Cl}$ & $c$-hexyl & $73 \pm 37$ \\
$\mathbf{5 c}$ & $\mathrm{OH}$ & $c$-pentyl & $102 \pm 16$ \\
$\mathbf{6 c}$ & $\mathrm{Cl}$ & $c$-pentyl & $108 \pm 18$ \\
$\mathbf{5 d}$ & $\mathrm{OH}$ & $c$-pent-2-enyl & $104 \pm 21$ \\
$\mathbf{6 d}$ & $\mathrm{Cl}$ & $c$-pent-2-enyl & $89 \pm 13$ \\
\hline
\end{tabular}

a The predominant 6-oxo tautomer of compounds 5 is shown in Scheme 1. 
Compounds $\mathbf{6 b}$ and $\mathbf{6 c}$ inhibit the OGG1 enzyme by $c a$. 30\%, followed by compounds $\mathbf{5 a}$, $\mathbf{5} \mathbf{b}$, and $\mathbf{6 d}$ at $c a$. 10\%-15\%, all at $0.2 \mathrm{mM}$ ligand concentration. Interestingly, the halogenated compounds seem in general to be better inhibitors than their 6-oxo derivatives. To check enzyme specificity, we tested the same seven compounds at the higher concentration of $0.5 \mathrm{mM}$ against NTH1, a structural but not functional homolog of OGG1. Both enzymes have a deep pocket for binding of oxidized bases; in general, OGG1 repairs oxidized purines while NTH1 is involved in repair of oxidized pyrimidines. Compound $\mathbf{6 b}$ reduced the NTH1 activity by around $25 \%$ at $0.5 \mathrm{mM}$ ligand concentration. An effect of varying the $N-9$ substituent is not so evident from the few compounds examined.

\section{Experimental Section}

\subsection{General Information}

${ }^{1} \mathrm{H}-\mathrm{NMR}$ spectra were recorded at $300 \mathrm{MHz}$ with a Bruker DPX 300, at $400 \mathrm{MHz}$ with a Bruker DPX 400 or at 600 with a Bruker AVI 600 instrument (Bruker BioSpin AG, Fällanden, Switzerland). The ${ }^{13} \mathrm{C}$-NMR spectra were recorded at 75,100 , or $150 \mathrm{MHz}$ with the Bruker instruments listed above. Assignments of ${ }^{1} \mathrm{H}$ and ${ }^{13} \mathrm{C}$ resonances are inferred from $1 \mathrm{D}{ }^{1} \mathrm{H}-\mathrm{NMR}, 1 \mathrm{D}{ }^{13} \mathrm{C}-\mathrm{NMR}$, DEPT, or APT, and 2D NMR (HMQC, HMBC) spectroscopical data. ${ }^{1} \mathrm{H}$ - and ${ }^{13} \mathrm{C}$-NMR spectra of all novel compounds can be found in the Supplementary Material (Figures S1-S18). HRMS (EI) was performed with a double-focusing magnetic sector VG Prospec Q instrument (Waters, Manchester, UK) and HRMS (ESI) with a TOF quadrupole Micromass QTOF $2 \mathrm{~W}$ instrument (Waters). Melting points were determined with a Büchi Melting point B-545 apparatus (Büchi Labortechnik AG, Flawil, Switzerland) and are uncorrected. Dry DMF and THF were obtained from a solvent purification system, MB SPS-800 (MBraun, Garching, Germany). Acetic anhydride and diisopropylamine were distilled over $\mathrm{CaH}_{2}$. DMSO was dried over activated $3 \AA$ molecular sieves for four days. Potassium carbonate was oven dried at $150{ }^{\circ} \mathrm{C}$ under high vacuum for $12 \mathrm{~h}$. A saturated aqueous solution of $\mathrm{Br}_{2}$ was prepared by stirring water $(20 \mathrm{~mL})$ with $\mathrm{Br}_{2}(0.200 \mathrm{~mL})$ in a closed container for $15 \mathrm{~min}$ at ambient temperature. Sodium hydride $(\mathrm{ca} .60 \%$ in mineral oil) was washed with dry pentane under inert atmosphere prior to use. All other reagents were commercially available and used as received. The following compounds were available by literature methods: Cyclohexyl tosylate [51], cyclopentenyl bromide [44], cyclopent-2-enol [52], cyclopentenyl acetate [53], 1b [29], 8 [30].

\subsection{Synthesis}

\subsubsection{2-Amino-6-chloro-9-(cyclohexylmethyl)-9H-purine (2a) and 2-Amino-6-chloro-7-} (cyclohexylmethyl)-7H-purine (3a)

Method $A: \mathrm{K}_{2} \mathrm{CO}_{3}(1.63 \mathrm{~g}, 11.8 \mathrm{mmol})$ was added to a stirring solution of compound $\mathbf{1 a}(1.00 \mathrm{~g}$, $5.90 \mathrm{mmol})$ in dry DMF (30 mL) at ambient temperature under $\mathrm{N}_{2}$. After $20 \mathrm{~min}$ bromomethylcyclohexane $(0.905 \mathrm{~mL}, 6.49 \mathrm{mmol})$ was added and the resulting mixture was stirred for $72 \mathrm{~h}$, filtered. and evaporated. The isomers were separated by flash chromatography on silica gel, eluting with $\mathrm{MeOH}-\mathrm{CH}_{2} \mathrm{Cl}_{2}$ (1:9) to yield $\mathbf{2 a}(1.05 \mathrm{~g}, 67 \%)$ and $\mathbf{3 a}(150 \mathrm{mg}, 10 \%)$. 
2a: colorless solid; mp $148-150{ }^{\circ} \mathrm{C}$ (lit. [54], 154-155 ${ }^{\circ} \mathrm{C}$ ); ${ }^{1} \mathrm{H}-\mathrm{NMR}$ (DMSO-d6, $\left.400 \mathrm{MHz}\right) \delta 8.10$ (s, $1 \mathrm{H}$, $\mathrm{H}-8), 6.91$ (s, 2H, NH 2$), 3.88$ (d, $\left.J=7.4 \mathrm{~Hz}, 2 \mathrm{H}, \mathrm{NCH}_{2}\right), 1.88-1.72$ (m, 1H, H-1 in $c$-hex), 1.68-1.52 (m, 3H, c-hex), 1.51-1.42 (m, 2H, c-hex), 1.19-1.02 (m, 3H, c-hex) 1.00-0.85 (m, 2H, c-hex); ${ }^{13} \mathrm{C}-\mathrm{NMR}$ (DMSO-d6, 100 MHz) $\delta 159.8$ (C, C-2), 154.3 (C, C-4), 149.3 (C, C-6), 143.7 (CH, C-8), 123.3 (C, C-5), $48.8\left(\mathrm{CH}_{2}, \mathrm{NCH}_{2}\right), 37.1(\mathrm{CH}, \mathrm{C}-1$ in $c$-hex $), 29.9\left(\mathrm{CH}_{2}, \mathrm{C}-3\right.$ and $\mathrm{C}-5$ in $c$-hex $), 25.8\left(\mathrm{CH}_{2}, \mathrm{C}-4\right.$ in $c$-hex), $25.0\left(\mathrm{CH}_{2}, \mathrm{C}-2\right.$ and $\mathrm{C}-6$ in $c$-hex); HREIMS $m / z 265.1092$ (calcd for $\left.\mathrm{C}_{12} \mathrm{H}_{16} \mathrm{ClN}_{5}, 265.1094\right)$. Spectral data were in good agreement with those reported before [54].

3a: colorless solid mp 228-231 ${ }^{\circ} \mathrm{C} .{ }^{1} \mathrm{H}-\mathrm{NMR}$ (DMSO-d6, $\left.400 \mathrm{MHz}\right) \delta 8.32(\mathrm{~s}, 1 \mathrm{H}, \mathrm{H}-8), 6.62(\mathrm{~s}, 2 \mathrm{H}$, $\left.\mathrm{NH}_{2}\right), 4.10\left(\mathrm{~d}, J=7.2 \mathrm{~Hz}, 2 \mathrm{H}, \mathrm{NCH}_{2}\right), 1.82-1.70$ (m, 1H, H-1 in $c$-hex), 1.69-1.54 (m, 3H, $c$-hex), 1.50-1.41 (m, 2H, c-hex), 1.24-1.06 (m, 3H, c-hex), 1.03-0.89 (m, 2H, c-hex); ${ }^{13} \mathrm{C}-\mathrm{NMR}$ (DMSO-d6, $100 \mathrm{MHz}) \delta 164.2$ (C, C-4), 159.9 (C, C-2), 149.8 (CH, C-8), 142.3 (C, C-6), 114.9 (C, C-5), 51.8 $\left(\mathrm{CH}_{2}, \mathrm{NCH}_{2}\right), 38.6(\mathrm{CH}, \mathrm{C}-1$ in $c$-hex $), 29.6\left(\mathrm{CH}_{2}, \mathrm{C}-3\right.$ and $\mathrm{C}-5$ in $c$-hex $), 25.8\left(\mathrm{CH}_{2}, \mathrm{C}-4\right.$ in $c$-hex $), 25.1$ $\left(\mathrm{CH}_{2}, \mathrm{C}-2\right.$ and $\mathrm{C}-3$ in $c$-hex); HREIMS $m / z 265.1096$ (calcd for $\mathrm{C}_{12} \mathrm{H}_{16} \mathrm{ClN} 5,265.1094$ ).

Method B: Compound 1a (200 mg, $1.18 \mathrm{mmol})$ was added to a solution of cyclohexylmethanol (141 mg, $1.24 \mathrm{mmol})$ and $\mathrm{PPh}_{3}(325 \mathrm{mg}, 1.24 \mathrm{mmol})$ in dry THF $(10 \mathrm{~mL})$ under $\mathrm{N}_{2}$. The resulting suspension was treated with diisopropyl azodicarboxylate (DIAD) $(0.244 \mathrm{~mL}, 1.24 \mathrm{mmol})$ and the reaction mixture was stirred at $70{ }^{\circ} \mathrm{C}$ for $7 \mathrm{~h}$ before cyclohexylmethanol (141 mg, $\left.1.24 \mathrm{mmol}\right), \mathrm{PPh}_{3}$ ( $325 \mathrm{mg}, 1.24 \mathrm{mmol})$, and DIAD $(0.244 \mathrm{~mL}, 1.24 \mathrm{mmol})$ were added. The mixture was stirred for another $7 \mathrm{~h}$ at $70{ }^{\circ} \mathrm{C}$, cooled, treated with brine $(10 \mathrm{~mL})$, and extracted with $\mathrm{CH}_{2} \mathrm{Cl}_{2}(3 \times 75 \mathrm{~mL})$. The combined organic layers were washed with water $(50 \mathrm{~mL})$, dried $\left(\mathrm{Na}_{2} \mathrm{SO}_{4}\right)$ and evaporated in vacuo. The isomers were separated by flash chromatography on silica gel eluting with EtOAc-Hexane (gradient; 70\%-100\% EtOAc) followed by $\mathrm{MeOH}-\mathrm{EtOAc}(1: 9)$ to yield $\mathbf{2 a}(240 \mathrm{mg}, 76 \%)$ and $\mathbf{3 a}$ (16 mg, 5\%).

\subsubsection{2-Amino-6-chloro-9-(cyclohexyl)-9H-purine (2b)}

Method A: The title compound was prepared from compound 1a (200 mg, $1.18 \mathrm{mmol}), \mathrm{K}_{2} \mathrm{CO}_{3}(326 \mathrm{mg}$, $2.36 \mathrm{mmol})$ and cyclohexyl tosylate $(450 \mathrm{mg}, 1.77 \mathrm{mmol})$ in DMF $(15 \mathrm{~mL})$ as described for the synthesis of compounds $\mathbf{2 a}$ above. MeOH-EtOAc (1:19) was used for flash chromatography to yield $\mathbf{2 b}$ (98 $\mathrm{mg}$, $33 \%$ ). Colorless needles; mp $163-165{ }^{\circ} \mathrm{C}$ (lit. [55], $165{ }^{\circ} \mathrm{C}$ ); ${ }^{1} \mathrm{H}-\mathrm{NMR}$ (DMSO- $\left.d_{6}, 400 \mathrm{MHz}\right) \delta 8.23(\mathrm{~s}, 1 \mathrm{H}$, $\mathrm{H}-8), 6.88$ (s, 2H, NH 2$), 4.28-4.12$ (m, 1H, H-1 in c-hex), 2.01-1.75 (m, 7H, c-hex), 1.45-1.17 (m, 3H, $c$-hex); ${ }^{13} \mathrm{C}-\mathrm{NMR}$ (DMSO-d6, $\left.100 \mathrm{MHz}\right) \delta 159.5$ (C, C-6), 153.5 (C, C-4), 149.3 (C, C-2), $141.2(\mathrm{CH}$, C-8), 123.5 (C, C-5), 53.5 (CH, C-1 in $c$-hex), $31.9\left(\mathrm{CH}_{2}, c\right.$-hex), $25.1\left(\mathrm{CH}_{2}, c\right.$-hex $), 24.7\left(\mathrm{CH}_{2}, c\right.$-hex); HREIMS $m / z 251.0934$ (calcd for $\mathrm{C}_{11} \mathrm{H}_{14} \mathrm{ClN}_{5}, 251.0938$ ). Spectral data were in good agreement with those reported before [55].

Method B: The title compound was prepared from compound 1a $(1.00 \mathrm{~g}, 5.90 \mathrm{mmol})$, cyclohexanol [2 $\times(620 \mathrm{mg}, 6.19 \mathrm{mmol})], \mathrm{PPh}_{3}[2 \times(1.62 \mathrm{~g}, 6.19 \mathrm{mmol})]$ and DIAD [2 $\times(1.22 \mathrm{~mL}, 6.19 \mathrm{mmol}]$ in THF $(50 \mathrm{~mL})$ as described for the synthesis of compounds $\mathbf{2 a}$ above. After each addition of cyclohexanol the mixture was subjected to sonication for $20 \mathrm{~min}$ using a sonicator probe. EtOAc-Hexane (gradient; $30 \%-100 \%$ EtOAc) was used for flash chromatography to yield $\mathbf{2 b}(295 \mathrm{mg}, 20 \%)$. 
3.2.3. 2-Amino-6-chloro-9-(cyclopentyl)-9H-purine (2c) and 2-Amino-6-chloro-7-(cyclopentyl)-7Hpurine (3c)

Method A: The title compounds were prepared from compound $1 \mathrm{a}(1.00 \mathrm{~g}, 5.90 \mathrm{mmol}), \mathrm{K}_{2} \mathrm{CO}_{3}(1.63 \mathrm{~g}$, $11.8 \mathrm{mmol})$ and bromocyclopentane $(0.696 \mathrm{~mL}, 6.49 \mathrm{mmol})$ in DMF $(50 \mathrm{~mL})$ as described for the synthesis of compounds $\mathbf{2 a}$ and $\mathbf{3 a}$ above. MeOH-EtOAc (1:19) was used for flash chromatography to yield 2c (994 mg, 71\%) and 3c (75 mg, 5\%).

2c: colorless solid; mp $137-140{ }^{\circ} \mathrm{C}$ (lit. [55], $142{ }^{\circ} \mathrm{C}$ ); ${ }^{1} \mathrm{H}-\mathrm{NMR}$ (DMSO- $\left.d_{6}, 400 \mathrm{MHz}\right) \delta 8.20(\mathrm{~s}, 1 \mathrm{H}$, $\mathrm{H}-8), 6.86$ (s, 2H, NH 2$), 4.77-4.65$ (m, 1H, H-1 in c-pent), 2.16-2.02 (m, 2H, c-pent) 2.00-1.75 (m, 4H, $c$-pent), 1.72-1.60 (m, 2H, c-pent); ${ }^{13} \mathrm{C}-\mathrm{NMR}$ (DMSO-d6, $\left.100 \mathrm{MHz}\right) \delta 159.3$ (C, C-2), 153.7 (C, C-4), 149.1 (C, C-6), 141.4 (CH, C-8), 123.5 (C, C-5), 55.1 (CH, C-1 in c-pent), $31.4\left(\mathrm{CH}_{2}, \mathrm{C}-3\right.$ and $\mathrm{C}-4$ in $c$-pent), $23.2\left(\mathrm{CH}_{2}, \mathrm{C}-2\right.$ and $\mathrm{C}$-5 in $c$-pent); HREIMS $m / z 237.0777$ (calcd for $\mathrm{C}_{10} \mathrm{H}_{12} \mathrm{ClN}_{5}, 237.0781$ ). Spectral data were in good agreement with those reported before $[34,55,56]$.

3c: colorless solid; $\mathrm{mp}>230{ }^{\circ} \mathrm{C}$ (dec.); ${ }^{1} \mathrm{H}-\mathrm{NMR}$ (DMSO-d $\left.6,400 \mathrm{MHz}\right) \delta 8.46$ (s, $1 \mathrm{H}, \mathrm{H}-8$ ), 6.59 (s, 2H, $\mathrm{NH}_{2}$ ), 5.11-5.01 (m, 1H, H-1 in c-pent), 2.24-2.10 (m, 2H, c-pent), 2.02-1.90 (m, 2H, c-pent), 1.86-1.62 (m, 4H, c-pent); ${ }^{13} \mathrm{C}-\mathrm{NMR}$ (DMSO-d6, $\left.100 \mathrm{MHz}\right) \delta 164.3$ (C, C-4), 159.7 (C, C-2), 146.6 $(\mathrm{CH}, \mathrm{C}-8), 142.2$ (C, C-6), 115.1 (C, C-5), $58.0\left(\mathrm{CH}, \mathrm{C}-1\right.$ in $c$-pent), $32.6\left(\mathrm{CH}_{2}, \mathrm{C}-3\right.$ and $\mathrm{C}-4$ in $c$-pent), $23.1\left(\mathrm{CH}_{2}, \mathrm{C}-2\right.$ and $\mathrm{C}-5$ in $c$-pent); HREIMS $m / z 237.0776$ (calcd for $\mathrm{C}_{10} \mathrm{H}_{12} \mathrm{ClN}_{5}, 237.0781$ ). Spectral data were in good agreement with those reported before [34,55].

Method B: The title compounds were prepared from compound 1a (200 mg, $1.18 \mathrm{mmol})$, cyclopentanol [2 $\times(107 \mathrm{mg}, 1.24 \mathrm{mmol})], \mathrm{PPh}_{3}[2 \times(325 \mathrm{mg}, 1.24 \mathrm{mmol})]$ and DIAD [2 $\left.\times(244 \mu \mathrm{L}, 1.24 \mathrm{mmol})\right]$ in THF $(10 \mathrm{~mL})$ as described for the synthesis of compounds 2a and 3a above. EtOAc-hexane (gradient; $70 \%-100 \%$ EtOAc) followed by $\mathrm{MeOH}-\mathrm{EtOAc}$ (1:9) were used for flash chromatography to 2c (202 $\mathrm{mg}, 72 \%)$ and $\mathbf{3 c}(6 \mathrm{mg}, 6 \%)$.

3.2.4. 2-Amino-6-chloro-9-(cyclopent-2-enyl)-9H-purine (2d) and 2-Amino-6-chloro-7-(cyclopent-2enyl)-7H-purine (3d)

Method $A$ : The title compound 2d was prepared from compound 1a (200 mg, $1.18 \mathrm{mmol}), \mathrm{K}_{2} \mathrm{CO}_{3}$ (490 mg, $3.54 \mathrm{mmol}$ ) and 3-bromocyclopentene ( $0.29 \mathrm{~mL}$, ca. $80 \%$ pure, ca. $2.4 \mathrm{mmol})$ in DMF (20 mL) as described for the synthesis of compounds $\mathbf{2 a}$ and $\mathbf{3 a}$ above, except that the reaction time was $24 \mathrm{~h}$. EtOAc-hexane (gradient; 50\%-100\% EtOAc) followed by MeOH-EtOAc (1:9) were used for flash chromatography to yield $\mathbf{2 d}\left(49 \mathrm{mg}, 18 \%\right.$ ). Colorless solid; mp $154-154.5^{\circ} \mathrm{C}$ (lit., [57] 166.0-166.7 ${ }^{\circ} \mathrm{C}$ ); ${ }^{1} \mathrm{H}-\mathrm{NMR}$ (DMSO-d6, $\left.400 \mathrm{MHz}\right) \delta 7.96$ (s, 1H, H-8), 6.88 (s, 2H, NH2), 6.26-6.18 (m, 1H, c-pent), 5.93-5.84 (m, 1H, c-pent), 5.51-5.41 (m, 1H, c-pent), 2.73-2.61 (m, 1H, c-pent), 2.47-2.36 (m, 2H, $c$-pent), 2.00-1.87 (m, 1H, c-pent); ${ }^{13} \mathrm{C}-\mathrm{NMR}$ (DMSO-d6, $\left.100 \mathrm{MHz}\right) \delta 159.6$ (C, C-6), 153.6 (C, C-4), 149.3 (C, C-2), 141.1 (CH, C-8), 137.3 (CH, C-2 in c-pent), 128.6 (CH, C-3 in $c$-pent), 123.6 (C, C-5), 59.4 (CH, C-1 in $c$-pent), 31.2 ( $\mathrm{CH}_{2}, \mathrm{C}$-5 in $c$-pent), 30.4 ( $\mathrm{CH}_{2}, \mathrm{C}-4$ in $c$-pent); HREIMS $m / z 235.0624$ (calcd for $\mathrm{C}_{10} \mathrm{H}_{10} \mathrm{ClN}_{5}$ 235.0625). Spectral data were in good agreement with those reported before [57]. 
Method B: The title compound 2d was prepared from compound 1a (340 mg, $2.01 \mathrm{mmol}$ ), cyclopent-2-enol $[2 \times(0.180 \mathrm{~mL}, 2.03 \mathrm{mmol})], \mathrm{PPh}_{3}[2 \times(531 \mathrm{mg}, 2.03 \mathrm{mmol})]$ and DIAD $[2 \times(0.442 \mathrm{~mL}$, $2.03 \mathrm{mmol})]$ in THF $(20 \mathrm{~mL})$ as described for the synthesis of compounds $\mathbf{2 a}$ and $\mathbf{3 a}$ above. EtOAc-Hexane (gradient; 70\%-100\% EtOAc) followed by MeOH-EtOAc (1:9) were used for flash chromatography to yield $\mathbf{2 d}$ (187 mg, 40\%).

Method C: A solution of compound $1 \mathrm{a}(100 \mathrm{mg}, 0.590 \mathrm{mmol})$ and $\mathrm{NaH}(18 \mathrm{mg}, 0.77 \mathrm{mmol})$ in dry DMSO $(5 \mathrm{~mL})$ was stirred at room temperature for $20 \mathrm{~min}$ under Ar atmosphere. The mixture was added to a solution of cyclopent-2-en-1-yl acetate $(0.070 \mathrm{~mL}, 0.77 \mathrm{mmol})$ and $\mathrm{Pd}\left(\mathrm{PPh}_{3}\right) 4(103 \mathrm{mg}, 0.0890 \mathrm{mmol})$ in dry DMSO $(5 \mathrm{~mL})$ and the resulting mixture was stirred at $50{ }^{\circ} \mathrm{C}$ for $48 \mathrm{~h}$ under Ar and evaporated in vacuo. The product was purified by flash chromatography as described in Method B to yield 2d (73 $\mathrm{mg}, 53 \%)$ and $\mathbf{3 d}(25 \mathrm{mg}, 18 \%)$.

3d: colorless solid; mp 155-157 ${ }^{\circ} \mathrm{C}$ (dec.); ${ }^{1} \mathrm{H}-\mathrm{NMR}$ (DMSO-d6, $400 \mathrm{MHz}$ ) $\delta 8.15$ (s, 1H, H-8), 6.61 (s, 2H, $\mathrm{NH}_{2}$ ), 6.34-6.28 (m, 1H, c-pent), 6.03-5.96 (m, 1H, c-pent), 5.82-5.75 (m, 1H, c-pent) 2.61-2.34 (m, 3H, c-pent) 1.96-1.83 (m, 1H, c-pent); ${ }^{13} \mathrm{C}-\mathrm{NMR}$ (DMSO- $\left.d 6,100 \mathrm{MHz}\right) \delta 164.4$ (C, C-4), 159.8 (C, C-2), 146.2 (CH, C-8), 142.3 (C, C-6), 138.3 (CH, C-2 in $c$-pent), 127.9 (CH, C-3 in $c$-pent), 114.8 (C, C-5), 62.5 (CH, C-1 in $c$-pent), 32.1 ( $\mathrm{CH}_{2}, \mathrm{C}-5$ in $c$-pent), $31.0\left(\mathrm{CH}_{2}, \mathrm{C}-4\right.$ in $c$-pent); HREIMS $\mathrm{m} / \mathrm{z}$ 235.0631 (calcd for $\mathrm{C}_{10} \mathrm{H}_{10} \mathrm{ClN} 5,235.0625$ ). Spectral data were in good agreement with those reported before [57].

3.2.5. 2-Acetamido-9-(cyclohexylmethyl)-9H-purin-6-yl diphenylcarbamate (2e) and 2-Acetamido-7(cyclohexylmethyl)-7H-purin-6-yl diphenylcarbamate (3e)

Method A: The title compounds were prepared from compound $\mathbf{1 b}(200 \mathrm{mg}, 0.515 \mathrm{mmol}), \mathrm{K}_{2} \mathrm{CO}_{3}$ $(142 \mathrm{mg}, 1.03 \mathrm{mmol})$ and bromomethylcyclohexane $(0.144 \mathrm{~mL}, 1.03 \mathrm{mmol})$ in DMF $(7 \mathrm{~mL})$ as described for the synthesis of compounds $\mathbf{2 a}$ and $\mathbf{3 a}$ above. $\mathrm{MeOH}-\mathrm{CH}_{2} \mathrm{Cl}_{2}$ (1:9) followed by $\mathrm{MeOH}-\mathrm{CH}_{2} \mathrm{Cl}_{2}$ (1:4) were used for flash chromatography to yield $\mathbf{2 e}(111 \mathrm{mg}, 45 \%)$ and $\mathbf{3 e}(18 \mathrm{mg}, 7 \%)$.

2e: colorless solid; mp. 192-194 ${ }^{\circ} \mathrm{C}$; ${ }^{1} \mathrm{H}-\mathrm{NMR}\left(\mathrm{CDCl}_{3}, 400 \mathrm{MHz}\right) \delta 7.97$ (s, 1H, NH), $7.87(\mathrm{~s}, 1 \mathrm{H}$, $\mathrm{H}-8), 7.47-7.24(\mathrm{~m}, 10 \mathrm{H}, \mathrm{Ph}), 3.99$ (d, $\left.J=7.0 \mathrm{~Hz}, 2 \mathrm{H}, \mathrm{NCH}_{2}\right), 2.58$ (s, 3H, CH$), 1.85$ (m, 1H, H-1 in $c$-hex), 1.78-1.58 (m, 5H, c-hex), 1.30-1.07 (m, 3H, c-hex), 1.07-0.92 (m, 2H, c-hex); ${ }^{13} \mathrm{C}-\mathrm{NMR}$ $\left(\mathrm{CDCl}_{3}, 100 \mathrm{MHz}\right) \delta 171.1(\mathrm{C}, \mathrm{CONH}), 156.2(\mathrm{C}, \mathrm{OCON}), 155.4(\mathrm{C}, \mathrm{C}-4), 152.2(\mathrm{C}, \mathrm{C}-2), 150.6(\mathrm{C}$, C-6), $144.4(\mathrm{CH}, \mathrm{C}-8), 141.9$ (C, Ph), $129.3(\mathrm{CH}, \mathrm{Ph}), 127.2$ (br, $\left.2 \times \mathrm{CH}_{2}, \mathrm{Ph}\right), 120.6$ (C, C-5), 50.5 $\left(\mathrm{CH}_{2}, \mathrm{NCH}_{2}\right), 38.4(\mathrm{CH}, \mathrm{C}-1$ in $c$-hex $), 30.8\left(\mathrm{CH}_{2}, \mathrm{C}-3\right.$ and $\mathrm{C}-5$ in $c$-hex $), 26.1\left(\mathrm{CH}_{2}, \mathrm{C}-4\right.$ in $c$-hex $), 25.6$ $\left(\mathrm{CH}_{2}, \mathrm{C}-2\right.$ and $\mathrm{C}-3$ in $c$-hex), $25.3\left(\mathrm{CH}_{3}\right)$; HRESIMS $m / z 485.2311$ (calcd for $\mathrm{C}_{27} \mathrm{H}_{29} \mathrm{~N}_{6} \mathrm{O}_{3}+1,485.2301$ ).

3e: colorless oil; ${ }^{1} \mathrm{H}-\mathrm{NMR}\left(\mathrm{CDCl}_{3}, 400 \mathrm{MHz}\right) \delta 8.10$ (s, 1H, NH), 7.96 (s, 1H, H-8), 7.42-7.36 (m, 8H, $\mathrm{Ph}$ ), 7.33-7.28 (m, 2H, Ph), 3.89 (d, $\left.J=7.2 \mathrm{~Hz}, 2 \mathrm{H}, \mathrm{NCH}_{2}\right), 2.63\left(\mathrm{~s}, 3 \mathrm{H}, \mathrm{CH}_{3}\right), 1.68-1.60(\mathrm{~m}, 3 \mathrm{H}$, $c$-hex), 1.45-1.35 (m, 2H, c-hex), 1.13-0.98 (m, 3H, c-hex), 0.92-0.72 (m, 3H, c-hex); ${ }^{13} \mathrm{C}-\mathrm{NMR}$ $\left(\mathrm{CDCl}_{3}, 100 \mathrm{MHz}\right) \delta 172.0(\mathrm{C}, \mathrm{CONH}), 164.9(\mathrm{C}-4), 152.2(\mathrm{C}, \mathrm{C}-2), 151.9(\mathrm{C}, \mathrm{OCON}), 149.5(\mathrm{C}$, C-6), $148.5(\mathrm{CH}, \mathrm{C}-8), 141.5$ (C, Ph), $129.6(\mathrm{CH}, \mathrm{Ph}), 127.6$ (br, $2 \times \mathrm{CH}, \mathrm{Ph}), 111.9$ (C, C-5), 53.8 $\left(\mathrm{CH}_{2}, \mathrm{NCH}_{2}\right), 38.9(\mathrm{CH}, \mathrm{C}-1$ in $c$-hex $), 30.3\left(\mathrm{CH}_{2}, \mathrm{C}-3\right.$ and $\mathrm{C}-5$ in $c$-hex $), 26.0\left(\mathrm{CH}_{2}, \mathrm{C}-4\right.$ in $c$-hex $) 25.4$ $\left(\mathrm{CH}_{2}, \mathrm{C}-2\right.$ and $\mathrm{C}-6$ in $c$-hex ), $25.6\left(\mathrm{CH}_{3}\right)$; HRESIMS $m / z 485.2313$ (calcd for $\mathrm{C}_{27} \mathrm{H}_{29} \mathrm{~N}_{6} \mathrm{O}_{3}+1,485.2301$ ). 
Method B: The title compounds were prepared from compound $\mathbf{1 b}$ (200 $\mathrm{mg}, 0.515 \mathrm{mmol}$ ), cyclohexylmethanol [2 $\times(62 \mathrm{mg}, 0.54 \mathrm{mmol})], \mathrm{PPh}_{3}[2 \times(142 \mathrm{mg}, 0.540 \mathrm{mmol})]$ and DIAD $[2 \times(0.106 \mathrm{~mL}$, $0.540 \mathrm{mmol})]$ in THF $(10 \mathrm{~mL})$ as described for the synthesis of compounds $\mathbf{2 a}$ and $\mathbf{3 a}$ above. EtOAc-Hexane (gradient; 70\%-100\% EtOAc) followed by MeOH-EtOAc (1:9) were used for flash chromatography to yield $\mathbf{2 e}(175 \mathrm{mg}, 70 \%)$ and $\mathbf{3 e}(7 \mathrm{mg}, 3 \%)$.

\subsubsection{2-Acetamido-9-(cyclohexyl)-9H-purin-6-yl diphenylcarbamate (2f)}

Method A: The title compound was prepared from compound $\mathbf{1 b}(500 \mathrm{mg}, 1.29 \mathrm{mmol}), \mathrm{K}_{2} \mathrm{CO}_{3}(329 \mathrm{mg}$, $2.38 \mathrm{mmol})$ and cyclohexyl tosylate $(441 \mathrm{mg}, 1.73 \mathrm{mmol})$ in THF $(15 \mathrm{~mL})$ as described for the synthesis of compounds 2a above. MeOH-EtOAc (1:19) was used for flash chromatography to yield $2 \mathbf{f}$ (180 $\mathrm{mg}$, 30\%). Off-white solid; mp 189-190 ${ }^{\circ} \mathrm{C}$; ${ }^{1} \mathrm{H}-\mathrm{NMR}$ (DMSO- $\left.d_{6}, 300 \mathrm{MHz}\right) \delta 10.67$ (s, $1 \mathrm{H}, \mathrm{NH}$ ), 8.55 (s, 1H, H-8), 7.54-7.38 (m, 8H, Ph), 7.37-7.25 (m, 2H), 4.46-4.28 (m, 1H, H-1 in c-hex), 2.20 (s, 3H, $\left.\mathrm{CH}_{3}\right)$, 2.06-1.80 (m, 6H, CH in $c$-hex), 1.76-1.65 (m, 1H, c-hex), 1.51-1.14 (m, 3H, c-hex); ${ }^{13} \mathrm{C}-\mathrm{NMR}$ (DMSO- $d_{6}$, $75 \mathrm{MHz}) \delta 168.8(\mathrm{C}, \mathrm{CONH}), 155.0$ (C, OCON), 154.3 (C, C-4), 151.7 (C, C-2), 150.3 (C, C-6), 144.1 (CH, C-8), $141.6(\mathrm{C}, \mathrm{Ph}), 129.4(\mathrm{CH}, \mathrm{Ph}), 127.1(\mathrm{CH}, \mathrm{Ph}), 120.1$ (C, C-5), 54.1 (CH, C-1 in c-hex), 31.9 $\left(\mathrm{CH}_{2}, \mathrm{C}-3\right.$ and $\mathrm{C}-5$ in $c$-hex $), 25.1\left(\mathrm{CH}_{2}, \mathrm{C}-2\right.$ and $\mathrm{C}-6$ in $c$-hex $), 24.7\left(\mathrm{CH}_{2}, \mathrm{C}-4\right.$ in $c$-hex $), 24.6\left(\mathrm{CH}_{3}\right)$; HREIMS $m / z$ 470.2057 (calcd for $\mathrm{C}_{26} \mathrm{H}_{26} \mathrm{~N}_{6} \mathrm{O}_{3}, 470.2066$ ).

Method B: The title compound was prepared from compound $\mathbf{1 b}(400 \mathrm{mg}, 1.03 \mathrm{mmol})$, cyclohexanol [2 $\times(108 \mathrm{mg}, 1.08 \mathrm{mmol})], \mathrm{PPh}_{3}[2 \times(284 \mathrm{mg}, 1.08 \mathrm{mmol})]$ and DIAD [2 $\left.\times(0.213 \mathrm{~mL}, 1.08 \mathrm{mmol})\right]$ in THF $(10 \mathrm{~mL})$ as described for the synthesis of compound $\mathbf{2 a}$ above. EtOAc-Hexane (gradient; $30 \%-100 \%$ EtOAc) was used for flash chromatography to yield $\mathbf{2 f}(107 \mathrm{mg}, 22 \%)$ as an off-white solid.

\subsubsection{2-Acetamido-9-(cyclopentyl)-9H-purin-6-yl diphenylcarbamate (2g)}

Method $A$ : The title compound $\mathbf{2 g}$ was prepared from compound $\mathbf{1 b}(389 \mathrm{mg}, 1.00 \mathrm{mmol}), \mathrm{K}_{2} \mathrm{CO}_{3}$ (277 mg, $2.00 \mathrm{mmol})$ and bromocyclopentane $(0.120 \mathrm{~mL}, 1.10 \mathrm{mmol})$ in DMF $(50 \mathrm{~mL})$ as described for the synthesis of compounds 2 a above. MeOH-EtOAc (1:19) was used for flash chromatography to yield 2 g (238 mg, 52\%). Colorless solid; mp 137-140 ${ }^{\circ} \mathrm{C}$; ${ }^{1} \mathrm{H}-\mathrm{NMR}$ (DMSO-d6, $\left.400 \mathrm{MHz}\right) \delta 10.62$ (s, $1 \mathrm{H}$, $\mathrm{NH}), 8.51$ (s, 1H, H-8), 7.53-7.40 (m, 8H, Ph), 7.36-7.27 (m, 2H, Ph), 4.79-4.62 (m, 1H, H-1 in $c$-pent), $2.21\left(\mathrm{~s}, 3 \mathrm{H}, \mathrm{CH}_{3}\right), 2.19-2.11$ (m, 2H, c-pent), 2.10-1.83 (m, 4H, c-pent), 1.77-1.62 (m, 2H, c-pent); ${ }^{13} \mathrm{C}-\mathrm{NMR}\left(\mathrm{DMSO}-d_{6}, 100 \mathrm{MHz}\right) \delta 168.8(\mathrm{C}, \mathrm{CONH}), 155.0(\mathrm{C}, \mathrm{OCON}), 154.6(\mathrm{C}, \mathrm{C}-4), 151.7$ (C, C-2), 150.2 (C, C-6), 144.4 (CH, C-8), 141.6 (C, Ph), 129.4 (CH, Ph), 127.2 (CH, Ph), 120.3 (C, C-5), 56.1 (CH, C-1 in c-pent), $31.7\left(\mathrm{CH}_{2}, \mathrm{C}-3\right.$ and $\mathrm{C}-4$ in $c$-pent $), 24.5\left(\mathrm{CH}_{3}\right), 23.5\left(\mathrm{CH}_{2}, \mathrm{C}-2\right.$ and $\mathrm{C}-5$ in $c$-pent), one Ph signal was hidden; HREIMS $m / z 456.1903$ (calcd for $\mathrm{C}_{25} \mathrm{H}_{24} \mathrm{~N}_{6} \mathrm{O}_{3}, 456.1910$ ).

Method B: The title compound $\mathbf{2 g}$ was prepared from compound $\mathbf{1 b}$ (389 $\mathrm{mg}, 1.00 \mathrm{mmol}$ ), cyclopentanol [2 $\times(91 \mathrm{mg}, 1.1 \mathrm{mmol})], \mathrm{PPh}_{3}[2 \times(276 \mathrm{mg}, 1.05 \mathrm{mmol})]$ and DIAD [2 $\left.\times(0.207 \mathrm{~mL}, 1.05 \mathrm{mmol})\right]$ in THF $(10 \mathrm{~mL})$ as described for the synthesis of compounds $\mathbf{2 a}$ above. EtOAc-Hexane (gradient; 70\%-100\% EtOAc) followed by $\mathrm{MeOH}-\mathrm{EtOAc}(1: 9)$ were used for flash chromatography to yield $\mathbf{2 g}$ (264 mg, 58\%). 


\subsubsection{2-Amino-8-bromo-6-chloro-9-(cyclohexylmethyl)-9H-purine (4a)}

Method A: Sat. aq. $\mathrm{Br}_{2}(50 \mathrm{~mL})$ was added dropwise to a rapidly stirred suspension of $\mathbf{2 a}(1.50 \mathrm{~g}$, $5.64 \mathrm{mmol})$ in water $(20 \mathrm{~mL})$ over $10 \mathrm{~min}$ at ambient temperature. The flask was closed and the reaction mixture was stirred for $74 \mathrm{~h}$. The flask was left open in the hood until all $\mathrm{Br}_{2}$ was evaporated before the water was removed in vacuo. The product was purified by flash chromatography on silica gel, eluting with EtOAc-Hexane (1:1) to yield $4 \mathbf{a}$ (1.55 g, 79\%). Yellow solid; mp 169-170 ${ }^{\circ} \mathrm{C}$. ${ }^{1} \mathrm{H}-\mathrm{NMR}$ (DMSO-d6, $400 \mathrm{MHz}) \delta 7.07$ (s, 2H, NH2), 3.86 (d, $\left.J=8.0 \mathrm{~Hz}, 2 \mathrm{H}, \mathrm{NCH}_{2}\right), 1.96-1.81$ (m, 1H, H-1 in $c$-hex), 1.72-1.44 (m, 5H, c-hex), 1.24-0.92 (m, 5H, c-hex); ${ }^{13} \mathrm{C}-\mathrm{NMR}$ (DMSO-d6, $\left.100 \mathrm{MHz}\right) \delta 159.7$ (C, C-2), 155.0 (C, C-4), 148.0 (C, C-6), 129.5 (C, C-8), 123.3 (C, C-5), $49.6\left(\mathrm{CH}_{2}, \mathrm{NCH}_{2}\right), 36.9$ (CH, c-hex), $30.0\left(\mathrm{CH}_{2}\right.$, $c$-hex), 25.7 ( $\mathrm{CH}_{2}, c$-hex), 25.1 ( $\mathrm{CH}_{2}, c$-hex); HREIMS $m / z 343.0198$ (calcd for $\mathrm{C}_{12} \mathrm{H}_{15} \mathrm{BrClN}_{5}, 343.0199$ ).

Method $B: \mathrm{K}_{2} \mathrm{CO}_{3}(231 \mathrm{mg}, 1.67 \mathrm{mmol})$ was added to a stirring solution of compound 10 (207 $\mathrm{mg}$, $0.833 \mathrm{mmol})$ in dry DMF $(15 \mathrm{~mL})$ at ambient temperature under $\mathrm{N}_{2}$. After $20 \mathrm{~min}$, bromomethylcyclohexane $(0.175 \mathrm{~mL}, 1.25 \mathrm{mmol})$ was added and the resulting mixture was stirred for $80 \mathrm{~h}$ before $\mathrm{K}_{2} \mathrm{CO}_{3}(115 \mathrm{mg}$, $0.835 \mathrm{mmol})$ and bromomethylcyclohexane $(0.175 \mathrm{~mL}, 1.25 \mathrm{mmol})$ was added and the mixture was stirred for additional $16 \mathrm{~h}$ and evaporated in vacuo. The product was purified by flash chromatography on silica gel eluting with EtOAc-Hexane (2:3) to yield $4 \mathbf{a}$ (98 mg, 34\%).

Method $C$ : The title compound was prepared from compound $\mathbf{1 0}$ (175 $\mathrm{mg}, 0.704 \mathrm{mmol}$ ), cyclohexylmethanol $[2 \times(0.091 \mathrm{~mL}, 0.74 \mathrm{mmol})], \mathrm{PPh}_{3}[2 \times(276 \mathrm{mg}, 0.740 \mathrm{mmol})]$ and DIAD $[2 \times(0.146 \mathrm{~mL}, 0.740 \mathrm{mmol})]$ in THF $(10 \mathrm{~mL})$ as described for the synthesis of compounds $2 \mathbf{a}$ above. EtOAc-Hexane (gradient; $20 \%-100 \%$ EtOAc) was used for flash chromatography to yield $4 \mathbf{a}$ (136 mg, 56\%).

\subsubsection{2-Amino-8-bromo-6-chloro-9-(cyclohexyl)-9H-purine (4b)}

The title compound was prepared from compound $\mathbf{2 b}(250 \mathrm{mg}, 0.993 \mathrm{mmol})$ and saturated aqueous $\mathrm{Br}_{2}(12 \mathrm{~mL})$ in water $(5 \mathrm{~mL})$ as described for the synthesis of compound $4 \mathbf{a}$ above. EtOAc-Hexane (1:1) was used for flash chromatography to yield $\mathbf{4 b}(229 \mathrm{mg}, 70 \%)$. Yellow solid; mp $181-183{ }^{\circ} \mathrm{C} ;{ }^{1} \mathrm{H}-\mathrm{NMR}$ (DMSO- $\left.d_{6}, 600 \mathrm{MHz}\right) \delta 6.98$ (br s, 2H, NH ), 4.35-4.22 (m, 1H, H-1 in c-hex), 2.46-2.27 (m, 2H, c-hex), 1.92-1.75 (m, 4H, c-hex), 1.74-1.62 (m, 1H, c-hex), 1.45-1.29 (m, 2H, c-hex), 1.28-1.12 (m, 1H, $c$-hex); ${ }^{13} \mathrm{C}-\mathrm{NMR}$ (DMSO-d6, $\left.150 \mathrm{MHz}\right) \delta 159.1$ (C, C-2), 154.5 (C, C-4), 148.2 (C, C-6), 128.6 (C, C-8), 123.7 (C, C-5), 57.6 (CH, C-1 in $c$-hex), $29.7\left(\mathrm{CH}_{2}, \mathrm{C}-3\right.$ and $\mathrm{C}-5$ in $c$-hex $), 25.3\left(\mathrm{CH}_{2}, \mathrm{C}-2\right.$ and $\mathrm{C}-6$ in $c$-hex), $24.6\left(\mathrm{CH}_{2}, \mathrm{C}-4\right.$ in $c$-hex); HRESIMS $m / z 330.0131$ (calcd for $\left.\mathrm{C}_{11} \mathrm{H}_{14} \mathrm{BrClN}_{5}+1,330.0121\right)$.

\subsubsection{2-Amino-8-bromo-6-chloro-9-(cyclopentyl)-9H-purine (4c)}

The title compound was prepared from compound $2 \mathbf{c}(880 \mathrm{mg}, 3.70 \mathrm{mmol})$ and sat. aq. $\mathrm{Br} 2(35 \mathrm{~mL})$ in water $(10 \mathrm{~mL})$ as described for the synthesis of compound $4 \mathbf{a}$ above. EtOAc-Hexane (1:1) was used for flash chromatography to yield $4 \mathbf{c}(950 \mathrm{mg}, 81 \%)$. Yellow solid; mp $172-174{ }^{\circ} \mathrm{C} ;{ }^{1} \mathrm{H}-\mathrm{NMR}$ (DMSO- $d 6$, $600 \mathrm{MHz}) \delta 6.97$ (s, 2H, NH ), 4.85-4.77 (m, 1H, H-1 in c-pent), 2.33-2.17 (m, 2H, c-pent), 2.11-1.87 (m, 4H, c-pent), 1.71-1.59 (m, 2H, c-pent); ${ }^{13} \mathrm{C}-\mathrm{NMR}$ (DMSO-d6, $\left.150 \mathrm{MHz}\right) \delta 159.1$ (C, C-2), 154.3 (C, C-4), 148.2 (C, C-6), 129.3 (C, C-8), 123.9 (C, C-5), 57.7 (CH, C-1 in c-pent), 29.7 (CH2, C-3 and C-4 in $c$-pent), $24.4\left(\mathrm{CH}_{2}, \mathrm{C}-2\right.$ and $\mathrm{C}$-5 in $c$-pent); HREIMS $m / z 314.9880$ (calcd for $\mathrm{C}_{10} \mathrm{H}_{11} \mathrm{BrClN}_{5}, 314.9886$ ). 


\subsubsection{2-Amino-8-bromo-6-chloro-9-(cyclopent-2-enyl)-9H-purine (4d)}

Method A: A solution of diisopropylamine $(0.145 \mathrm{~mL}, 1.03 \mathrm{mmol})$ in dry THF $(3 \mathrm{~mL})$ was stirred at $-78^{\circ} \mathrm{C}$ under Ar. $n$-BuLi (0.536 mL, $1.00 \mathrm{mmol}, 1.87 \mathrm{M}$ in hexane) was added dropwise. After stirring for $30 \mathrm{~min}$, a solution of compound $\mathbf{2 d}(118 \mathrm{mg}, 0.500 \mathrm{mmol})$ in THF $(1.5 \mathrm{~mL})$ was added. After additional stirring for $1 \mathrm{~h}$ at $-78{ }^{\circ} \mathrm{C}$, a solution of $\mathrm{CBrCl}_{2} \mathrm{CBrCl}_{2}(326 \mathrm{mg}, 1.00 \mathrm{mmol})$ in THF $(1.5 \mathrm{~mL})$ was added dropwise and the resulting mixture was stirred at $-78{ }^{\circ} \mathrm{C}$ for $1 \mathrm{~h}$, and then $10 \mathrm{~min}$ without cooling. Saturated aqueous $\mathrm{NH}_{4} \mathrm{Cl}(5 \mathrm{~mL})$ was added and the resulting mixture was extracted with EtOAc $(3 \times 50 \mathrm{~mL})$. The combined organic extracts were washed with brine $(100 \mathrm{~mL})$, dried $\left(\mathrm{MgSO}_{4}\right)$, and evaporated in vacuo. The product was purified by flash chromatography on silica gel eluting with EtOAc-Hexane (1:1) to yield 4d (50 mg, 32\%). Buff solid; mp 157-158 ${ }^{\circ} \mathrm{C}$ (dec.); ${ }^{1} \mathrm{H}-\mathrm{NMR}$ (DMSO-d6, $600 \mathrm{MHz}) \delta 6.95\left(\mathrm{~s}, 2 \mathrm{H}, \mathrm{NH}_{2}\right), 6.15-6.13$ (m, 1H, c-pent), 5.74-5.72 (m, 1H, c-pent), 5.69-5.60 (m, 1H, c-pent) 2.90-2.79 (m, 1H, c-pent), 2.48-2.36 (m, 2H, c-pent), 2.22-2.14 (m, 1H, c-pent); ${ }^{13} \mathrm{C}$-NMR (DMSO-d6, $150 \mathrm{MHz}) \delta 159.3$ (C, C-2), 154.4 (C-4), 148.0 (C, C-6), 136.5 (CH, C-3 in c-pent), 128.0 (C, C-8), 127.7 (CH, C-2 in c-pent), 123.5 (C-5), 62.1 (CH, C-1 in c-pent), 32.0 ( $\mathrm{CH}_{2}, \mathrm{C}-5$ in $c$-pent), $27.9\left(\mathrm{CH}_{2}, \mathrm{C}-4\right.$ in $c$-pent); HREIMS $m / z 312.9734$ (calcd for $\mathrm{C}_{10} \mathrm{H}_{9} \mathrm{BrClN}_{5}, 312.9730$ ).

Method B: Compound 10 (64 mg, $0.26 \mathrm{mmol}$ ) was added to a cooled solution of cyclopent-2-en-1-ol (44 mg, $0.51 \mathrm{mmol}$ ) and $\mathrm{PPh}_{3}(135 \mathrm{mg}, 0.515 \mathrm{mmol})$ in anhydrous THF (5 mL) under Ar. The resulting suspension was treated with diethyl azodicarboxylate (DEAD, $0.080 \mathrm{~mL}, 0.51 \mathrm{mmol})$ and the resulting mixture was stirred at ambient temperature for $1 \mathrm{~h}$ and at $70{ }^{\circ} \mathrm{C}$ for $15 \mathrm{~h}$. The mixture was cooled, treated with brine $(50 \mathrm{~mL})$, and extracted with $\mathrm{CH}_{2} \mathrm{Cl}_{2}(3 \times 50 \mathrm{~mL})$. The combined organic layer was washed with water $(10 \mathrm{~mL})$, dried $\left(\mathrm{Na}_{2} \mathrm{SO}_{4}\right)$, and evaporated in vacuo. The product was purified by flash chromatography on silica gel eluting with EtOAc-Hexane (3:7) to yield 4d (34 mg, 42\%).

Method C: A solution of compound $10(110 \mathrm{mg}, 0.423 \mathrm{mmol})$ and $\mathrm{NaH}(16 \mathrm{mg}, 0.67 \mathrm{mmol})$ in dry DMF (10 mL) was stirred at ambient temperature for $20 \mathrm{~min}$ under $\mathrm{Ar} . \mathrm{Pd}\left(\mathrm{PPh}_{3}\right)_{4}(77 \mathrm{mg}, 0.067 \mathrm{mmol})$ and cyclopent-2-en-1-yl acetate $(84 \mathrm{mg}, 0.66 \mathrm{mmol})$ were added, and the resulting mixture was stirred at $55^{\circ} \mathrm{C}$. After three days $\mathrm{Pd}\left(\mathrm{PPh}_{3}\right)_{4}(77 \mathrm{mg}, 0.067 \mathrm{mmol})$ and cyclopent-2-en-1-yl acetate $(84 \mathrm{mg}, 0.66 \mathrm{mmol})$ were added. The reaction mixture was stirred for three more days and evaporated under in vacuo. The product was purified by flash chromatography on silica gel eluting with EtOAc-Hexane (gradient 50\%-100\% EtOAc) followed by MeOH-EtOAc (1:9) to yield 4d (41 mg, 29\%).

\subsubsection{9-(Cyclohexylmethyl)-8-oxoguanine (5a)}

A mixture of compound $4 \mathrm{a}(263 \mathrm{mg}, 0.763 \mathrm{mmol}), \mathrm{NaOAc}(319 \mathrm{mg}, 3.89 \mathrm{mmol})$, glacial AcOH (9 mL), and $\mathrm{Ac}_{2} \mathrm{O}(1.5 \mathrm{~mL}, 17 \mathrm{mmol})$ was stirred at reflux under $\mathrm{N}_{2}$ for $16 \mathrm{~h}$, before the mixture was cooled and evaporated in vacuo. The residue was suspended in water $(3 \mathrm{~mL})$ and stirred at ambient temperature while the $\mathrm{pH}$ was adjusted to 13 by dropwise addition of $10 \mathrm{M} \mathrm{NaOH}$ (aq). The resulting solution was refluxed for $20 \mathrm{~min}$, cooled to $0{ }^{\circ} \mathrm{C}$, and stirred while the $\mathrm{pH}$ was brought down to 7 by dropwise addition of $6 \mathrm{M} \mathrm{HCl}$ (aqueous). The precipitate was collected and dried in vacuo. The product was purified by flash chromatography on silica gel eluting with $\mathrm{MeOH}-\mathrm{CH}_{2} \mathrm{Cl}_{2}(1: 4)$ to yield 5a (160 mg, 80\%). Pinkish solid; mp 297-300 ${ }^{\circ} \mathrm{C}$; ${ }^{1} \mathrm{H}-\mathrm{NMR}$ (DMSO-d6, $\left.400 \mathrm{MHz}\right) \delta 10.57$ (s, $\left.1 \mathrm{H}, \mathrm{NH}\right), 10.48$ (s, 1H, NH), 6.43 (s, 2H, $\mathrm{NH}_{2}$ ), 3.42 (d, $J=7.4 \mathrm{~Hz}, 2 \mathrm{H}, \mathrm{NCH}_{2}$ ), 1.85-1.71 (m, 1H, H-1 in $c$-hex), 1.69-1.48 (m, 5H, $c$-hex), 
1.19-1.06 (m, 3H, c-hex), 0.98-0.85 (m, 2H, c-hex); ${ }^{13} \mathrm{C}-\mathrm{NMR}$ (DMSO-d6, $\left.100 \mathrm{MHz}\right) \delta 153.4$ (C, C-6), 152.6 (C, C-8), 150.9 (C, C-2), 148.2 (C, C-4), 98.0 (C, C-5), $44.9\left(\mathrm{CH}_{2}, \mathrm{NCH}_{2}\right), 36.3$ (CH, C-1 in c-hex), $30.1\left(\mathrm{CH}_{2}, \mathrm{C}-3\right.$ and $\mathrm{C}-5$ in in $c$-hex $), 25.9\left(\mathrm{CH}_{2}, \mathrm{C}-4\right.$ in $c$-hex $), 25.1\left(\mathrm{CH}_{2}, \mathrm{C}-2\right.$ and $\mathrm{C}-6$ in $c$-hex); HREIMS $m / z 263.1380$ (calcd for $\mathrm{C}_{12} \mathrm{H}_{17} \mathrm{~N}_{5} \mathrm{O}_{2}, 263.1382$ ).

3.2.13. 9-(Cyclohexyl)-8-oxoguanine (5b) and 2-Amino-6-chloro-9-cyclohexyl-7H-purin-8(9H)-one (6b)

The title compounds were prepared from compound $4 \mathbf{b}$ (186 mg, $0.563 \mathrm{mmol}), \mathrm{NaOAc}(231 \mathrm{mg}$, $2.81 \mathrm{mmol})$, glacial $\mathrm{AcOH}(7 \mathrm{~mL})$, and $\mathrm{Ac}_{2} \mathrm{O}(1.20 \mathrm{~mL}, 12.7 \mathrm{mmol})$ as described for the synthesis of compound 5a above, except that the reflux time with $\mathrm{NaOH}$ was $4 \mathrm{~h}$. MeOH-EtOAc (1:9) was used for flash chromatography to yield $\mathbf{5 b}(106 \mathrm{mg}, 76 \%)$ and $\mathbf{6 b}$ (7 mg, 11\%).

5b: colorless solid; mp 367-368 ${ }^{\circ} \mathrm{C} ;{ }^{1} \mathrm{H}-\mathrm{NMR}$ (DMSO- $\left.d_{6}, 400 \mathrm{MHz}\right) \delta 10.57$ (s, 1H, NH), 10.45 (s, 1H, $\mathrm{NH}), 6.37$ (s, 2H, NH 2$), 4.04-3.91$ (m, 1H, H-1 in $c$-hex), 2.28-2.11 (m, 2H, c-hex), 1.86-1.71 (m, 2H, $c$-hex), 1.69-1.52 (m, 3H, c-hex), 1.36-1.04 (m, 3H, $c$-hex); ${ }^{13} \mathrm{C}-\mathrm{NMR}$ (DMSO- $\left.d_{6}, 100 \mathrm{MHz}\right) \delta 152.9$ (C, C-6), 151.8 (C, C-8), 150.9 (C, C-2), 147.7 (C, C-4), 98.1 (C, C-5), 51.2 (CH, C-1 in c-hex), 29.5 $\left(\mathrm{CH}_{2}, \mathrm{C}-3\right.$ and $\mathrm{C}-5$ in $c$-hex $), 25.5\left(\mathrm{CH}_{2}, \mathrm{C}-2\right.$ and $\mathrm{C}-6$ in $c$-hex $), 24.8\left(\mathrm{CH}_{2}, \mathrm{C}-4\right.$ in $c$-hex $)$; HREIMS $m / z$ 249.1222 (calcd for $\mathrm{C}_{11} \mathrm{H}_{15} \mathrm{~N}_{5} \mathrm{O}_{2}, 249.1226$ ).

6b: yellow solid mp 320-321 ${ }^{\circ} \mathrm{C}$; ${ }^{1} \mathrm{H}-\mathrm{NMR}$ (DMSO-d6, $\left.300 \mathrm{MHz}\right) \delta 11.20$ (br s, 1H, NH), 6.54 (s, 2H, $\mathrm{NH}_{2}$ ), 4.12-3.98 (m, 1H, H-1 in $c$-hex), 2.27-2.12 (m, 2H, c-hex), 1.88-1.75 (m, 2H, $c$-hex), 1.73-1.58 (m, 3H, c-hex), 1.39-1.09 (m, 3H, c-hex); ${ }^{13} \mathrm{C}-\mathrm{NMR}$ (DMSO-d6, $75 \mathrm{MHz}$ ) $\delta 158.3$ (C, C-8), 152.5 (C, C-4), 152.3 (C, C-2), 135.5 (C, C-6), 109.8 (C, C-5), 51.7 (CH, C-1 in $c$-hex), $29.1\left(\mathrm{CH}_{2}, \mathrm{C}-3\right.$ and C-5 in $c$-hex), $25.4\left(\mathrm{CH}_{2}, \mathrm{C}-2\right.$ and C-6 in $c$-hex), $24.8\left(\mathrm{CH}_{2}, \mathrm{C}-4\right.$ in $c$-hex); HREIMS $m / z 267.0877$ (calcd for $\left.\mathrm{C}_{11} \mathrm{H}_{14} \mathrm{ClN} 5 \mathrm{O}, 267.0887\right)$.

3.2.14. 9-(Cyclopentyl)-8-oxoguanine (5c) and 2-Amino-6-chloro-9-cyclopentyl-7H-purin-8(9H)-one (6c)

The title compounds were prepared from compound 4c (250 mg, $0.790 \mathrm{mmol}), \mathrm{NaOAc}(325 \mathrm{mg}$, $3.96 \mathrm{mmol})$, glacial $\mathrm{AcOH}(10 \mathrm{~mL})$, and $\mathrm{Ac}_{2} \mathrm{O}(3.00 \mathrm{~mL}, 31.6 \mathrm{mmol})$ as described for the synthesis of compound 5a above, except that the refluxing time with $\mathrm{NaOH}$ was $6 \mathrm{~h}$. MeOH-EtOAc (1:9) was used for flash chromatography to yield $\mathbf{5 c}$ (130 mg, 70\%) and $\mathbf{6 c}$ (12 $\mathrm{mg}, 6 \%)$.

5c: colorless solid; mp 309-310 ${ }^{\circ} \mathrm{C} ;{ }^{1} \mathrm{H}-\mathrm{NMR}$ (DMSO-d6, $\left.400 \mathrm{MHz}\right) \delta 10.58(\mathrm{~s}, 1 \mathrm{H}, \mathrm{NH}), 10.47(\mathrm{~s}, 1 \mathrm{H}$, $\mathrm{NH}), 6.35$ (s, 2H, NH ), 4.46-4.42 (m, 1H, H-1 in c-pent), 2.17-2.01 (m, 2H, c-pent), 1.94-1.73 (m, 4H, c-pent), $1.63-1.50$ (m, 2H, c-pent); ${ }^{13} \mathrm{C}-\mathrm{NMR}$ (DMSO-d6, $\left.100 \mathrm{MHz}\right) \delta 152.9$ (C, C-6), 151.9 (C, C-8), 150.9 (C, C-2), 147.8 (C, C-4), 98.2 (C, C-5), 51.8 (CH, C-1 in c-pent), $29.0\left(\mathrm{CH}_{2}, \mathrm{C}-2\right.$ and C-5 in $c$-pent), $24.3\left(\mathrm{CH}_{2}, \mathrm{C}\right.$-3 and C-4 in c-pent); HREIMS $m / z$ 235.1067 (calcd for $\mathrm{C}_{10} \mathrm{H}_{13} \mathrm{~N}_{5} \mathrm{O}_{2}, 235.1069$ ).

6c: colorless solid; mp 321-322 ${ }^{\circ} \mathrm{C}$ (dec.); ${ }^{1} \mathrm{H}-\mathrm{NMR}$ (DMSO-d6, $\left.400 \mathrm{MHz}\right) \delta 11.20$ (s, 1H, NH), 6.52 (s, 2H, $\mathrm{NH}_{2}$ ), 4.70-4.46 (m, 1H, c-pent), 2.20-2.01 (m, 2H, c-pent), 1.98-1.74 (m, 4H, c-pent), 1.68-1.50 (m, 2H, c-pent); ${ }^{13} \mathrm{C}-\mathrm{NMR}$ (DMSO- $\left.d_{6}, 100 \mathrm{MHz}\right) \delta 158.3$ (C, C-4), 152.6 (C, C-8), 152.2 (C, C-6), 135.5 (C, C-2), 109.9 (C, C-5), 52.1 (CH, C-1 in c-pent), 28.7 ( $\mathrm{CH}_{2}, \mathrm{C}-2$ and C-5 in $c$-pent), $24.3\left(\mathrm{CH}_{2}, \mathrm{C}-3\right.$ and $\mathrm{C}-4$ in $c$-pent); HREIMS $m / z 253.0727$ (calcd for $\mathrm{C}_{10} \mathrm{H}_{12} \mathrm{ClN}_{5} \mathrm{O}, 253.0734$ ). 
3.2.15. 9-(Cyclopent-2-enyl)-8-oxoguanine (5d) and 2-Amino-6-chloro-9-(cyclopent-2-enyl)-7Hpurin-8(9H)-one (6d)

The title compounds were prepared from compound $4 \mathbf{d}(210 \mathrm{mg}, 0.668 \mathrm{mmol}), \mathrm{NaOAc}(274 \mathrm{mg}$, $3.34 \mathrm{mmol})$, glacial $\mathrm{AcOH}(8 \mathrm{~mL})$, and $\mathrm{Ac}_{2} \mathrm{O}(2.78 \mathrm{~mL}, 29.4 \mathrm{mmol})$ as described for the synthesis of compound 5a above, except that the refluxing time with $\mathrm{NaOH}$ was $30 \mathrm{~h}$ and the heating bath was kept at $160{ }^{\circ} \mathrm{C}$ in the first reaction step. Glacial $\mathrm{AcOH}$ was used for the final neutralization and EtOAc followed by $\mathrm{MeOH}-\mathrm{EtOAc}$ (1:9) were used for flash chromatography to yield 5d (119 mg, 71\%) and 6d (9 mg, 5\%).

5d: colorless solid; mp 322-325 ${ }^{\circ} \mathrm{C}$ (dec.); ${ }^{1} \mathrm{H}-\mathrm{NMR}$ (DMSO-d $6,400 \mathrm{MHz}$ ) $\delta 10.60$ (s, 1H, NH), 10.49 $(\mathrm{s}, 1 \mathrm{H}, \mathrm{NH}), 6.34\left(\mathrm{~s}, 2 \mathrm{H}, \mathrm{NH}_{2}\right), 5.99-5.96(\mathrm{~m}, 1 \mathrm{H}, \mathrm{H}-3$ in $c$-pent), 5.62-5.59 (m, 1H, H-2 in $c$-pent), 5.30-5.21 (m, 1H, H-1 in c-pent), 2.79-2.63 (m, 1H, H-5 in $c$-pent), 2.40-2.26 (m, 1H, H-5b in $c$-pent), 2.24-2.13 (m, 1H, H-4a in c-pent), 2.13-2.03 (m, 1H, H-4b in c-pent); ${ }^{13} \mathrm{C}-\mathrm{NMR}$ (DMSO-d6, $100 \mathrm{MHz}$ ) $\delta 153.0$ (C, C-6), 151.8 (C, C-8), 151.0 (C, C-2), 147.7 (C, C-4), 134.5 (CH, C-3 in c-pent), 129.0 (CH, $\mathrm{C}$-2 in $c$-pent), $98.3(\mathrm{C}, \mathrm{C}-5), 56.8\left(\mathrm{CH}, \mathrm{C}\right.$-1 in $c$-pent), $31.8\left(\mathrm{CH}_{2}, \mathrm{C}-4\right.$ in $c$-pent $), 27.4\left(\mathrm{CH}_{2}, \mathrm{C}-5\right.$ in $c$-pent); HREIMS $m / z 233.0914$ (calcd for $\mathrm{C}_{10} \mathrm{H}_{11} \mathrm{~N}_{5} \mathrm{O}_{2}, 233.0913$ ).

6d: yellow solid; mp 310-310.5 ${ }^{\circ} \mathrm{C} ;{ }^{1} \mathrm{H}-\mathrm{NMR}$ (DMSO-d6, $\left.300 \mathrm{MHz}\right) \delta 11.18(\mathrm{~s}, 1 \mathrm{H}, \mathrm{NH}), 6.48(\mathrm{~s}, 2 \mathrm{H}$, $\mathrm{NH}_{2}$ ), 6.06-6.02 (m, 1H, H-3 in c-pent), 5.65-5.61 (m, 1H, H-2 in $c$-pent), 5.37-5.27 (m, 1H, H-1 in $c$-pent), 2.84-2.69 (m, 1H, H-5a in $c$-pent), 2.43-2.05 (m, 3H, c-pent); ${ }^{13} \mathrm{C}-\mathrm{NMR}$ (DMSO- $d 6,75 \mathrm{MHz}$ ) $\delta 158.3$ (C, C-8), 152.4 (C, C-4), 152.1 (C, C-2), 135.4 (C, C-6), 135.3 (CH, C-3 in c-pent), $128.1(\mathrm{CH}$, $\mathrm{C}$-2 in $c$-pent), 109.9 (C, C-5), $57.2\left(\mathrm{CH}, \mathrm{C}-1\right.$ in $c$-pent), $31.8\left(\mathrm{CH}_{2}, \mathrm{C}-5\right.$ in $c$-pent $), 27.0\left(\mathrm{CH}_{2}, \mathrm{C}-4\right.$ in $c$-pent); HREIMS $m / z 251.0568$ (calcd for $\mathrm{C}_{10} \mathrm{H}_{10} \mathrm{ClN}_{5} \mathrm{O}, 251.0574$ ).

\subsubsection{N-[9-(Cyclohexylmethyl)-6-oxo-6,9-dihydro-1H-purin-2-yl]acetamide (7)}

Method A: $\operatorname{Br} 2(33 \mathrm{mg}, 0.21 \mathrm{mmol})$ was added slowly to a stirred solution of compound $2 \mathrm{e}(20 \mathrm{mg}$, $0.41 \mathrm{mmol})$ in $\mathrm{CHCl}_{3}(4 \mathrm{~mL})$ and the resulting mixture was stirred for $6 \mathrm{~h}$ at ambient temperature. The reaction mixture was evaporated to dryness and the product was purified by flash chromatography on silica gel eluting with MeOH-EtOAc (1:19) to yield 7 (10 mg, 84\%). Off-white solid; mp 271-273 ${ }^{\circ} \mathrm{C}$ (dec.); ${ }^{1} \mathrm{H}-\mathrm{NMR}$ (DMSO-d6, $\left.400 \mathrm{MHz}\right) \delta 12.01$ (s, 1H, N2 H) 11.63 (s, 1H, NH), 7.95 (s, 1H, H-8), 3.90 (d, $\left.J=7.4 \mathrm{~Hz}, 2 \mathrm{H}, \mathrm{NCH}_{2}\right), 2.17$ (s, 3H, $\left.\mathrm{CH}_{3}\right), 1.88-1.74$ (m, 1H, $c$-hex), 1.70-1.54 (m, 3H, $c$-hex), 1.53-1.44 (m, 2H, c-hex), 1.21-1.07 (m, 3H, c-hex), 1.01-0.87 (m, 2H, c-hex); ${ }^{13} \mathrm{C}-\mathrm{NMR}$ (DMSO-d6, $100 \mathrm{MHz}) \delta 173.5\left(\mathrm{C}, \mathrm{CON}^{2}\right), 154.9(\mathrm{C}, \mathrm{C}-6), 148.8$ (C, C-4), 147.6 (C, C-2), 140.2 (CH, C-8), 120.0 (C, C-5), $48.9\left(\mathrm{CH}_{2}, \mathrm{NCH}_{2}\right), 37.4(\mathrm{CH}, \mathrm{C}-1$ in $c$-hex $), 29.9\left(\mathrm{CH}_{2}, \mathrm{C}-3\right.$ and $\mathrm{C}-5$ in $c$-hex $), 25.8\left(\mathrm{CH}_{2}\right.$, C-4 in $c$-hex), $25.0\left(\mathrm{CH}_{2}, \mathrm{C}\right.$-2 and C-6 in $c$-hex), $23.8\left(\mathrm{CH}_{3}\right)$; HREIMS $\mathrm{m} / \mathrm{z} 289.1534$ (calcd for $\left.\mathrm{C}_{14} \mathrm{H}_{19} \mathrm{~N}_{5} \mathrm{O}_{2}, 289.1539\right)$.

Method B: The title compound was prepared from compound 2 e (20 mg, $0.41 \mathrm{mmol})$, diisopropylamine (0.012 mL, $0.83 \mathrm{mmol}), n$-BuLi $\left(0.060 \mathrm{~mL}, 0.83 \mathrm{mmol}, 1.4 \mathrm{M}\right.$ in hexane) and $\mathrm{CBrCl}_{2} \mathrm{CBrCl}_{2}(27 \mathrm{mg}$, $0.83 \mathrm{mmol}$ ) in THF (tot. vol. $3 \mathrm{~mL}$ ) as described for the synthesis of compound $\mathbf{4 d}$ above, except that the reaction was stirred at $-78{ }^{\circ} \mathrm{C}$ for $2 \mathrm{~h}$ after the addition of $\mathrm{CBrCl}_{2} \mathrm{CBrCl}_{2}$. The product was purified by flash chromatography as described above to yield 7 (7 $\mathrm{mg}, 59 \%)$. 


\subsubsection{8-Bromo-6-chloro- $N$,9-bis(tetrahydro-2H-pyran-2-yl)-9H-purin-2-amine (9)}

The title compound was prepared from compound $8(1.00 \mathrm{~g}, 2.96 \mathrm{mmol})$, diisopropylamine $(0.84 \mathrm{~mL}$, $5.9 \mathrm{mmol}$ ), $n$-BuLi (4.23 mL, $5.20 \mathrm{mmol}, 1.4 \mathrm{M}$ in hexane), and $\mathrm{CBrCl}_{2} \mathrm{CBrCl}_{2}$ (1.93 g, $5.92 \mathrm{mmol}$ ) in THF (tot. vol. $30 \mathrm{~mL}$ ) as described for the synthesis of compound $\mathbf{4 d}$ above, except that the reaction was stirred at $-78{ }^{\circ} \mathrm{C}$ for $2 \mathrm{~h}$ after the addition of $\mathrm{CBrCl}_{2} \mathrm{CBrCl}_{2}$. EtOAc-Hexane (1:1) was used for flash chromatography to yield 9 (987 mg, 80\%). Colorless solid; mp $145-147{ }^{\circ} \mathrm{C}$ (dec.); ${ }^{1} \mathrm{H}-\mathrm{NMR}$ (DMSO- $d 6$, $300 \mathrm{MHz}) \delta 8.23(\mathrm{~s}, 1 \mathrm{H}, \mathrm{NH}), 5.52$ (dd, $J=11.0,2.4 \mathrm{~Hz}, 1 \mathrm{H}, \mathrm{CH}$ in THP), 5.13-5.02 (m, 1H, CH in THP), 4.10-3.97 (m, 1H, $\mathrm{OCH}_{2}$ in THP), 3.89-3.77 (m, 1H, OCH $\mathrm{OCH}_{2}$ inP), 3.69-3.56 (m, 1H, $\mathrm{OCH}_{2}$ in THP), 3.49-3.39 (m, 1H, $\mathrm{OCH}_{2}$ in THP), 3.14-2.90 (m, 1H, THP) $2.06-1.29$ (m, 11H, $\mathrm{CH}_{2}$ in THP); ${ }^{13} \mathrm{C}-\mathrm{NMR}$ (DMSO-d6, 75 MHz) $\delta 157.2$ (C, C-2), 154.2 (C, C-8), 148.3 (C, C-6), 129.5 (C, C-4), 124.3 (C, C-5), 84.4 (CH, N9-THP), 80.2 (CH, THP), 68.0 ( $\mathrm{CH}_{2}, \mathrm{OCH}_{2}$ in THP), 65.7 ( $\mathrm{CH}_{2}, \mathrm{OCH}_{2}$ in THP), 30.1, 27.6, 24.9, 24.5, 22.6 and 22.5 (all $\mathrm{CH}_{2}$, THP); HREIMS $m / z$ 415.0417 (calcd for $\mathrm{C}_{15} \mathrm{H}_{19} \mathrm{BrClN}_{5} \mathrm{O}_{2}, 415.0411$ ).

\subsubsection{2-Amino-8-bromo-6-chloro-1H-purine (10)}

A mixture compound 9 (150 mg, $0.360 \mathrm{mmol}), 96 \% \mathrm{EtOH}(10 \mathrm{~mL})$ and $9.6 \mathrm{M} \mathrm{HCl}(0.5 \mathrm{~mL})$, was stirred at ambient temperature for $30 \mathrm{~min}$ and neutralized by the addition of solid $\mathrm{KHCO}_{3}$. The resulting mixture was evaporated in vacuo and the product was isolated by flash chromatography on silica gel eluting with $\mathrm{MeOH}-\mathrm{CHCl}_{3}$ (1:50:) to yield 10 (80 mg, 90\%) as a yellow solid; $\mathrm{mp}>300{ }^{\circ} \mathrm{C}$ (dec.). ${ }^{1} \mathrm{H}-\mathrm{NMR}$ (DMSO- $\left.d_{6}, 400 \mathrm{MHz}\right) \delta 13.65(\mathrm{~s}, 1 \mathrm{H}, \mathrm{NH}), 6.88\left(\mathrm{~s}, 2 \mathrm{H}, \mathrm{NH}_{2}\right) ;{ }^{13} \mathrm{C}-\mathrm{NMR}$ (DMSO- $\left.d_{6}, 100 \mathrm{MHz}\right)$ $\delta$ 159.7, 156.2, 147.1, 126.5, 124.0; HREIMS $m / z$ 246.9257 (calcd for $\mathrm{C}_{5} \mathrm{H}_{3} \mathrm{BrClN}_{5}, 246.9260$ ). Spectral data were in good agreement with those reported before [48].

\subsection{DNA Glycosylase Activity Assay}

The enzyme OGG1 (residues 12-327) was diluted to the desired concentration (60 pM) using a protein dilution buffer (15\% glycerol, $1 \mathrm{mM}$ EDTA, $25 \mathrm{mM}$ HEPES pH 7.9, $1 \mathrm{mM}$ DTT, $0.1 \mu \mathrm{g} / \mu \mathrm{L} \mathrm{BSA}$ ). Enzyme, compound 5 or $6(0.2 \mathrm{mM})$, and $5^{\prime}{ }^{32} \mathrm{P}$ end-labeled duplex DNA containing an 8-oxo-G/C base pair were mixed in a $10 \mu \mathrm{L}$ reaction volume of $50 \mathrm{mM}$ MOPS $\mathrm{pH} 7.5,1 \mathrm{mM}$ EDTA, 5\% glycerol, and $1 \mathrm{mM}$ DTT. The sequence of the damaged strand in the DNA substrate used is 5'-GCATGCCTGCA CGG-80xoG-CATGGCCAGATCCCCGGGTACCGAG-3', which was annealed with a complementary strand containing a $\mathrm{C}$ opposite 8 oxoG. The reactions were incubated for $10 \mathrm{~min}$ at $37^{\circ} \mathrm{C}$, followed by addition of $2.5 \mu \mathrm{L} 0.5 \mathrm{M} \mathrm{NaOH}$ and incubation for $20 \mathrm{~min}$ at $70{ }^{\circ} \mathrm{C}$, in order to stop the reaction and ensure complete strand cleavage. Then $0.5 \mathrm{M} \mathrm{HCl} / 0.25 \mathrm{M}$ MOPS pH $7.5(2.5 \mu \mathrm{L})$ was added to each sample to neutralize the $\mathrm{pH}$. Formamide DNA loading buffer $(15 \mu \mathrm{L})$ was added to the reaction mixtures and the samples were incubated at $95{ }^{\circ} \mathrm{C}$ for $5 \mathrm{~min}$ to denature the DNA. The reaction products were analyzed on $20 \%$ denaturing urea gels. The gels were transferred to $3 \mathrm{M}$ paper and dried at $80{ }^{\circ} \mathrm{C}$ for $45 \mathrm{~min}$. The dry gels were placed in a storage phosphor screen overnight, and subsequently scanned on a Typhoon 9410 Variable Mode Image. ImageQuant TL Version 2003.02 (Amersham Biosciences, Piscataway, NJ, USA) was used to analyze the results. For human NTH1, the same procedure was followed, except that the DNA substrate contained a 5-hydroxyuracil/G base pair instead of the 8oxoG/C pair in the OGG1 
substrate. The concentration of NTH1 was $3 \mathrm{nM}$ to make sure the activity in the assay was within the linear range. Compounds were screened at $0.5 \mathrm{mM}$ concentration.

\section{Conclusions}

Synthetic routes to 8-oxoguanines have been examined. The best reaction sequence from chloroguanine 1a to the target compounds was found to be $N-9$ alkylation, C-8 bromination, and finally simultaneous hydrolysis of both halides. Bromination before $N$-alkylation should only be considered in cases where the $N$-substituent is not compatible with bromination conditions, since a bromide in the purine 8-position lowers the reactivity in $\mathrm{N}$-alkylations. In most cases, alkylation with an alkyl halide in the presence of a base compared favorably to reactions under Mitsunobu conditions. 2-Amino-6-chloropurine (1a) turned out to be a superior guanine precursor compared to the $O$-carbamoylguanine $\mathbf{1 b}$. The latter did not result in improved $\mathrm{N}-9$ selectivity in the alkylation and was not compatible with standard reaction conditions for C-8 bromination.

Enzymatic assays show that partly hydrolyzed 6-chloro-8-oxopurines 6 are somewhat better OGG1 inhibitors than the 8-oxoguanines $\mathbf{5}$. However, an inhibitory effect was only observed when using at least $0.2 \mathrm{mM}$ concentration of the compounds, suggesting that the R-group should be extended even further to make more interactions with the enzyme's substrate recognition pocket. Further, testing of the same compounds at a 2.5-fold higher concentration against human NTH1, which is a structural homolog of OGG1, showed that the synthesized compounds do not inhibit NTH1 at $0.5 \mathrm{mM}$, except possibly for a weak effect for compound $\mathbf{6 b}$. To develop these compounds into more potent inhibitors of OGG1, one possibility is to try compounds with more ribose-like R-groups. In the present study, the R-group contains a cyclic hydrocarbon only, and it would also be interesting to replace this with carbocyclic 2'-deoxyribose derivatives, as in antiviral drugs like abacavir and entecavir. In these nucleoside analog drugs, the R-group is not particularly larger than the R-group in our study, but it contains 5' and/or 3' hydroxyl groups. Since the structure of the OGG1 enzyme is known [7], molecular modeling will be included in the search for more potent OGG1 inhibitors in the future.

\section{Supplementary Material}

Supplementary materials can be accessed at: http://www.mdpi.com/1420-3049/20/09/15944/s1.

\section{Acknowledgments}

The Molecular Life Science program at the University of Oslo MLS ${ }^{\mathrm{UiO}}$ is gratefully acknowledged for a grant to Tushar R. Mahajan and the Research Council of Norway (RCN) for partial financing of the Bruker Avance instruments used in this study. Bjørn Dalhus is supported by the South-Eastern Norway Regional Health Authority (Grant No. 2014034) and Mari Eknes Ytre-Arne is supported by RCN (project No. 228563). Support from the Anders Jahres Foundation for Medical Research to BD is also acknowledged. 


\section{Author Contributions}

LLG and BD designed the research. TRM performed the synthetic organic chemistry, and MEYA and PSA the biological experiments. All authors contributed to writing the paper and read and approved the final manuscript.

\section{Conflicts of Interest}

The authors declare no conflict of interest.

\section{References}

1. Chabner, B.A.; Roberts, T.G., Jr. Chemotherapy and the war on cancer. Nat. Rev. Cancer 2005, 5, $65-72$.

2. Madhusudan, S.; Middleton, M.R. The emerging role of DNA repair proteins as predictive, prognostic and therapeutic targets in cancer. Cancer Treat. Rev. 2005, 31, 603-617.

3. Helleday, T.; Petermann, E.; Lundin, C.; Hodgson, B.; Sharma, R.A. DNA repair pathways as targets for cancer therapy. Nat. Rev. Cancer 2008, 8, 193-204.

4. Plummer, R. Perspective on the pipeline of drugs being developed with modulation of DNA damage as a target. Clin. Cancer Res. 2010, 16, 4527-4531.

5. Pallis, A.G.; Karamouzis, M.W. DNA repair pathways and their implication in cancer treatment. Cancer Metast. Rev. 2010, 29, 677-685.

6. See for instance: Dalhus, B.; Lærdahl, J.K.; Backe, P.H.; Bjørås, M. DNA base repair-recognition and initiation of catalysis. FEMS Microbiol. Rev. 2009, 33, 1044-1078.

7. Bruner, S.D.; Norman, D.P.G.; Verdine, G.L. Structural basis for recognition and repair of the endogenous mutagen 8-oxoguanine in DNA. Nature 2000, 403, 859-866.

8. Siah, H.-S.M.; Gundersen, L.-L.; Gørbitz, C.H. NMR and X-ray structural studies on 3-benzyl-8bromoadenine. J. Heterocycl. Chem. 2011, 48, 1375-1378.

9. Siah, H.-S.M.; Gundersen, L.-L. Synthetic strategies to 9-substituted 8-oxoadenines. Synth. Commun. 2013, 43, 1469-1476.

10. Perini, F.; Tieckelmann, H. Conversion of ureidomalonates and 5-carbalkoxyhydantoins to 5-ureido-4,6-pyrimidinediones. J. Org. Chem. 1970, 35, 812-816.

11. Brown, R.; Joseph, M.; Leigh, T.; Swain, M.L. Synthesis and reactions of 7,8-dihydro-8-methylpterin and 9-methylguanine 7-oxide. J. Chem. Soc. Perkin 1977, 1, 1003-1009.

12. Müller, H.; Carell, T.A. Carbocyclic analog of the oxidatively generated DNA lesion spiroiminodihydantoin. Eur. J. Org. Chem. 2007, 1438-1445.

13. Robins, M.J.; Hatfield, P.W.; Balzarini, J.; de Clercq, E. Nucleic acid related compounds. 47. Synthesis and biological activities of pyrimidine and purine "acyclic" nucleoside analogs. J. Med. Chem. 1984, $27,1486-1492$.

14. Michael, M.A.; Cottam, H.B.; Smee, D.F.; Robins, R.K.; Kini, G.D. Alkylpurines as immunopotentiating agents. Synthesis and antiviral activity of certain alkylguanines. J. Med. Chem. 1993, 36, 3431-3437. 
15. Zheng, Q.-H.; Wang, J.-Q.; Fei, X.; Hutchins, G.D. Synthesis of 8-methoxypenciclovir and 8-methoxyganciclovir through methyl triflate, a new potential approach to label penciclovir and ganciclovir with carbon-11. Synthesis 2003, 2785-2794.

16. DeClue, M.S.; Monnard, P.-A.; Bailey, J.A.; Maurer, S.E.; Collins, G.E.; Ziock, H.-J.; Rasmussen, S.; Boncella, J.M. Nucleobase mediated, photocatalytic vesicle formation from an ester precursor. J. Am. Chem. Soc. 2009, 131, 931-933.

17. Kaiya, T.; Ohta, M.; Kohda, K. Electrophilic amination of imidazole moieties of 9-ethylguanine and 1-methylbenzimidazole derivatives and reactivities of $\mathrm{N}$-aminated products. Tetrahedron 1993, 49, 8795-8804.

18. Werbovetz, K.A.; Macdonald, T.L. On the mechanism of arylamine-DNA adduct formation. Bioorg. Med. Chem. Lett. 1994, 4, 2323-2326.

19. Kaiya, T.; Fujiwara, T.; Kohda, K. Syntheses and properties of 1-methyl-3-phenylaminobenzimidazolium salts, models of DNA adducts of N7-arylaminodeoxyguanosinium salt. Chem. Res. Toxicol. 2000, 13, 993-1001.

20. Ferenc, G.; Padar, P.; Szolomajer, J.; Kovacs, L. N-alkylated guanine derivatives. Curr. Org. Chem. 2009, 13, 1085-1135.

21. Kjellberg, J.; Liljenberg, M.; Johansson, N.G. Regioselective alkylation of 6-( $\beta$-methoxyethoxy) guanine to give the 9-alkylguanine derivative. Tetrahedron Lett. 1986, 27, 877-880.

22. Kjellberg, J.; Hagberg, C.E.; Malm, A.; Noren, J.O.; Johansson, N.G. Studies on the Alkylation of Guanine. 2. The synthesis of acyclic guanosine analogs via the precursor 7-methyl-10-oxo-9,10dihydropyrimido[1,2-a]purine. Acta Chem. Scand. B 1986, 40, 310-312.

23. Kjellberg, J.; Johansson, N.G. Regioselective alkylation of guanine via diacyloxyglyoxal$\mathrm{N}^{2}$-acetylguanine adduct to obtain 7-alkylguanine derivatives. Studies on alkylation of guanine I. J. Heterocycl. Chem. 1986, 23, 625-627.

24. Kjellberg, J.; Johansson, N.G. Studies on the alkylation of derivatives of guanines. Nucleosides Nucleotides 1989, 8, 225-256.

25. Geen, G.R.; Kincey, P.M.; Choudary, B.M. Regiospecific Michael additions with 2-aminopurines. Tetrahedron Lett. 1992, 33, 4609-4612.

26. Bisacchi, G.S.; Singh, J.; Godfrey, J.D., Jr.; Kissick, T.P.; Mitt, T.; Malley, M.F.; di Marco, J.D.; Gougoutas, J.Z.; Mueller, R.H.; Zahler, R. Regioselective coupling of tetraalkylammonium salts of 6-iodo-2-aminopurine to a cyclobutyl triflate: Efficient preparation of homochiral BMS-180,194, a potent antiviral carbocyclic nucleoside. J. Org. Chem. 1995, 60, 2902-2905.

27. Geen, G.R.; Kincey, P.M.; Spoors, P.G. Regioselective alkylation of guanines using 2-acetoxytetrahydrofurans. Tetrahedron Lett. 2001, 42, 1781-1784.

28. Zou, R.; Robbins, M.J. High-yield regioselective synthesis of 9-glycosyl guanine nucleosides and analogues via coupling with 2- $\mathrm{N}$-acetyl-6-O-diphenylcarbamoylguanine. Can. J. Chem. 1987, 65, 1436-1437.

29. Dalpozzo, R.; de Nino, A.; Maiuolo, L.; Procopio, A.; de Munno, G.; Sindona, G. 9-Vinylguanine: an easy access to aza-analogs of 2',3'-dideoxyguanosine. Tetrahedron 2001, 57, 4035-4038.

30. Hocek, M.; Holy, A. A facile synthesis of 6-cyanopurine bases. Collect. Czech. Chem. Commun. 1995, 60, 1386-1389. 
31. Langli, G.; Gundersen, L.-L.; Rise, F. Regiochemistry in Stille couplings of 2,6-dihalopurines. Tetrahedron 1996, 52, 5625-5638.

32. Brændvang, M.; Gundersen, L.-L. Synthesis, biological activity and SAR of antimycobacterial 2and 8-substituted 6-(2-furyl)-9-(p-methoxybenzyl)purines. Bioorg. Med. Chem. 2007, 15, 7144-7165.

33. Toyota, A.; Katagiri, N.; Kaneko, C. Mitsunobu reactions for the synthesis of carbocyclic analogues of nucleosides: Examination of the regioselectivity. Synth. Commun. 1993, 23, 1295-1305.

34. Toyota, A.; Katagiri, N.; Kaneko, C. Synthesis of nucleosides and related compounds. 31. The alkylation of 2-amino-6-chloropurine with alcohols by Mitsunobu reaction for a synthesis of carbocyclic guanosine analogs. Heterocycles 1993, 36, 1625-1630.

35. Maruyama, T.; Kozai, S.; Uchida, M. Synthesis of $N$-aryl uracils and hypoxanthines and their biological properties. Nucleosides Nucleotides 1999, 18, 661-671.

36. Lu, W.; Sengupta, S.; Peterson, J.L.; Akhmedow, N.G.; Shi, X. Mitsunobu coupling of nucleobases and alcohols: An efficient, practical synthesis for novel nonsugar carbon nucleosides. J. Org. Chem. 2007, 72, 5012-5015.

37. Trost, B.M.; Madsen, R.; Guile, S.G.; Brown, B. Palladium-catalyzed enantioselective synthesis of carbanucleosides. J. Am. Chem. Soc. 2000, 122, 5947-5956.

38. Choo, H.; Chong, Y.; Chu, C.K. Solid phase synthesis of carbocyclic 1-2'-deoxynucleosides. Org. Lett. 2001, 3, 1471-1473.

39. Guillarme, S.; Legoupy, S.; Aubertin, A.-M.; Olicard, C.; Bourgougnon, N.; Huet, F. Rapid access to acyclic nucleosides via conjugate addition. Tetrahedron 2003, 59, 2177-2184.

40. Velcicky, J.; Lanver, A.; Lex, J.; Prokop, A.; Wieder, T.; Schmalz, H.-G. Transition-metal-mediated synthesis of novel carbocyclic nucleoside analogues with antitumoral activity. Chem. Eur. J. 2004, 10, 5087-5110.

41. Pautus, S.; Sehr, P.; Lewis, J.; Fortune, A.; Wolkerstorfer, A.; Szolar, O.; Guilligay, D.; Lunardi, T.; Decout, J.-L.; Cusack, S. New 7-methylguanine derivatives targeting the influenza polymerase PB2 Cap-binding domain. J. Med. Chem. 2013, 56, 8915-8930.

42. Roberts, J.D.; Chambers, V.C. Small-ring compounds. VIII. Some nucleophilic displacement reactions of cyclopropyl, cyclobutyl, cyclopentyl and cyclohexyl $p$-toluenesulfonates and halides. $J$. Am. Chem. Soc. 1951, 73, 5034-5040.

43. For a review of Pd-catalyzed $N$-allylation of purines, see for instance: Gundersen, L.-L. Metal-mediated $\mathrm{C}-\mathrm{C}$ and $\mathrm{C}-\mathrm{N}$ bond formation in the synthesis of bioactive purines. Targets Heterocycl. Syst. 2008, 12, 85-119.

44. Kobayashi, S.; Kawamoto, T.; Uehara, S.; Fukuyama, T.; Ryu, I. Black-light-induced radical/ionic hydroxymethylation of alkyl iodides with atmospheric $\mathrm{CO}$ in the presence of tetrabutylammonium borohydride. Org. Lett. 2010, 12, 1548-1551.

45. Gamadeku, T.; Gundersen, L.-L. Synthesis of 8-bromo- $N$-benzylpurines via 8-lithiated purines; Scopes and Limitations. Synth. Commun. 2010, 40, 2723-2735.

46. Marzouk, V.H.R.; Hennum, M.; Gundersen, L.-L. Efficient synthesis of cytotoxic pyrido[1,2-e] purines from purines employing direct C-allylation and RCM-oxidation as key-steps. Tetrahedron Lett. 2013, 54, 3437-3439.

47. Ikehara, M.; Tada, H.; Muneyama, K. Synthesis of 8-hydroxypurine nucleosides. Chem. Pharm. Bull. 1965, 13, 1140-1142. 
48. Jang, M.-Y.; Lin, Y.; de Jonghe, S.; Gao, L.-J.; Vanderhoydonck, B.; Froeyen, M.; Rozenski, J.; Herman, J.; Louat, T.; van Belle, K.; et al. Discovery of 7-N-piperazinylthiazolo[5,4- $d]$ pyrimidine analogues as a novel class of immunosuppressive agents with in vivo biological activity. J. Med. Chem. 2011, 54, 655-668.

49. Hagiya, K.; Muramoto, N.; Misaki, T.; Sugimura, T. DMEAD: A new dialkyl azodicarboxylate for the Mitsunobu reaction. Tetrahedron 2009, 65, 6109-6114.

50. Fromme, J.C.; Bruner, S.D.; Yang, W.; Karplus, M.; Verdine, G.L. Product-assisted catalysis in base-excision DNA repair. Nat. Struct. Biol. 2003, 10, 204-211.

51. Winstein, S.; Grunwald, E.; Buckles, R.E.; Hanso, C. The role of neighboring groups in replacement reactions. XI. Some reactivities involving neighboring groups. J. Am. Chem. Soc. 1948, 70, 816-821.

52. Forkel, N.V.; Henderson, D.A.; Fuchter, M.J. Lanthanide replacement in organic synthesis: Luche-type reduction of $\alpha, \beta$-unsaturated ketones in the presence of calcium triflate. Green Chem. 2012, 14, 2129-2132.

53. Jacquet, O.; Bergholz, T.; Magnier-Bouvier, C.; Mellah, M.; Guillot, R.; Fiaud, J.-C. Palladium-catalyzed and samarium-promoted coupling of stereochemically-biased allylic acetates with carbonyl compounds. Tetrahedron 2010, 66, 222-226.

54. Kim, K.; McComas, W. Chemoselective high-throughput purification mediated by solid-supported reagents: Its application to the first 6,9-disubstituted purine library synthesis. Comb. Chem. High Throughput Screen. 2000, 3, 125-129.

55. Legraverend, M.; Ludwig, O.; Bisagni, E.; Leclerc, S.; Meijer, L.; Giocanti, N.; Sadri, R.; Favaudon, V. Synthesis and in vitro evaluation of novel 2,6,9-trisubstituted purines acting as cyclin-dependent kinase inhibitors. Bioorg. Med. Chem. 1999, 7, 1281-1293.

56. Lukin, K.A.; Yang, C.X.; Bellettini, J.R.; Narayanan, B.A. New purine derivatives as efficient preparation of nucleoside analogs via alkylation. Nucleosides Nucleotides Nucleic Acids 2000, 19, 815-825.

57. Gültekin, Z. Palladium-catalyzed synthesis of 9-(2-cyclopentenyl)guanine. Asian J. Chem. 2006, $18,1462-1466$.

Sample Availability: Not available.

(C) 2015 by the authors; licensee MDPI, Basel, Switzerland. This article is an open access article distributed under the terms and conditions of the Creative Commons Attribution license (http://creativecommons.org/licenses/by/4.0/). 